Published in final edited form as:

Bioconjug Chem. 2019 June 19; 30(6): 1677-1689. doi:10.1021/acs.bioconjchem.9b00239.

\title{
Affibody-Indocyanine Green Based Contrast Agent for Photoacoustic and Fluorescence Molecular Imaging of B7-H3 Expression in Breast Cancer
}

\author{
Rakesh Bam ${ }^{\dagger}$, Makenna Laffey ${ }^{\dagger}$, Katharine Nottberg ${ }^{\dagger}$, Patrick S. Lown ${ }^{\ddagger}$, Benjamin J. \\ Hackel ${ }^{\ddagger}$, Katheryne E. Wilson ${ }^{\star}, \dagger$ \\ †Department of Radiology, Stanford University, Stanford, California 94305, United States \\ ¥Department of Chemical Engineering and Materials Science, University of Minnesota, \\ Minneapolis, Minnesota 55455, United States
}

\begin{abstract}
Spectroscopic photoacoustic (sPA) molecular imaging has high potential for identification of exogenous contrast agents targeted to specific markers. Antibody-dye conjugates have recently been used extensively for preclinical sPA and other optical imaging modalities for highly specific molecular imaging of breast cancer. However, antibody-based agents suffer from long circulation times that limit image specificity. Here, the efficacy of a small protein scaffold, the affibody (ABY), conjugated to indocyanine green (ICG), a near-infrared fluorescence dye, as a targeted molecular imaging probe is demonstrated. In particular, B7-H3 (CD276), a cellular receptor expressed in breast cancer, was imaged via SPA and fluorescence molecular imaging to differentiate invasive tumors from normal glands in mice. Administration of ICG conjugated to an

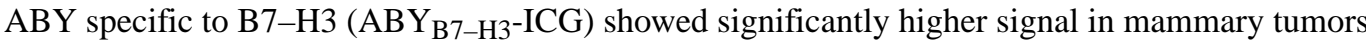
compared to normal glands of mice. $\mathrm{ABY}_{\mathrm{B} 7-\mathrm{H} 3}-\mathrm{ICG}$ is a compelling scaffold for molecular sPA imaging for breast cancer detection.
\end{abstract}

\section{Graphical Abstract}

\footnotetext{
*Corresponding Author: wilsonk2@stanford.edu. Author Contributions

R.B. conducted all the experiments, analyzed the data, and wrote the manuscript. M.L. and K.N. produced the contrast agent, assisted in the experiments, and analyzed the data. P.L. and B.H. identified the protein sequence used in the contrast agent. K.E.W. designed and conceptualized the study and aided in conducting the experiments and analyzing data. All authors read and revised the manuscript. Supporting Information

The Supporting Information is available free of charge on the ACS Publications website at DOI: 10.1021/acs.bioconjchem.9b00239 Figures: Characterization of control ABY, in vitro binding of $\mathrm{ABY}$ to cells, in vivo fluorescence imaging with control contrast agent, immunofluorescence staining of mammary tumors and normal glands. ABY protein sequence. Method: Immunofluorescence staining of tissue sections. (PDF)

The authors declare no competing financial interest.
} 


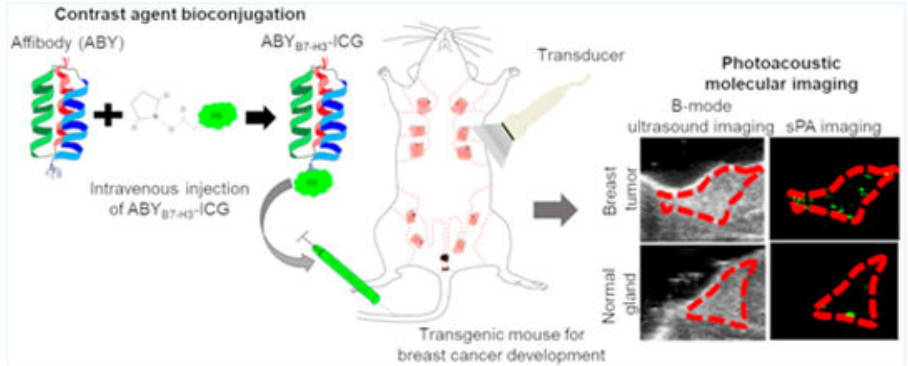

\section{INTRODUCTION}

The breast is the most common site for cancer development, responsible for $30 \%$ of all new cancer cases - approximately 268,600 new diagnoses-and the second leading cause of cancer-related mortality in women with a predicted 41,760 deaths in the United States in 2019. ${ }^{1}$ However, survival rates are significantly improved when the cancer is detected during early, localized stages of disease, with a five-year survival rate of $99 \%$, compared to $27 \%$ in highly advanced stages. ${ }^{1}$ Mammography is the first line imaging method for breast cancer screening but has limited sensitivity in patients with dense breast tissue, a subgroup with a four to six times greater risk of developing the disease. ${ }^{2}$ Half of the women between the age of 40 and 74 years have either heterogeneously dense (40\%) or extremely dense (10\%) breasts. Breast density is now being recognized as a high-risk factor for breast cancer. ${ }^{3}$ While ultrasound (US) imaging can be used as a supplemental screening method for such patients, it suffers from low positive predictive values (as low as 6.5\%) resulting in frequent patient recalls and unnecessary biopsies. ${ }^{4-6}$ Improved screening modalities with the ability to distinguish between benign and malignant disease are needed for earlier, more specific breast cancer detection, especially in those patients with dense breasts.

Photoacoustic (PA) imaging is an emerging tool for radiological diagnostics and could complement US imaging for breast cancer detection. ${ }^{7,8}$ Development of molecularly targeted contrast agents for PA molecular imaging may further improve breast cancer early detection rates. In PA imaging, short (10 ns or less) pulses of laser are localized to target tissues, which result in optical absorption initiated thermal expansion and subsequent generation of acoustic waves detectable by standard US equipment. The resulting acoustic transients can be reconstructed similarly to standard B-mode US images but represent a spatial map of optical absorption by endogenous or exogenous chromophores. As optical absorption is wavelength dependent, multiwavelength spectroscopic photoacoustic (sPA) imaging can separate acoustic signals originating from various photoabsorbers within a heterogeneous tissue environment based on known optical absorption spectra and provide relative concentrations within the tissues, ${ }^{9}$ enhancing signal-to-background ratios of the chromophores of interest. Due to low optical absorption and US scattering in breast tissue, it has been demonstrated that malignant lesions in the dense breast tissues can be visualized using PA imaging at high resolution and depth of up to 5-7 cm, making PA advantageous for breast imaging. ${ }^{10}$ Furthermore, molecularly targeted probes designed to accumulate in tumor tissue can enhance sPA signal from tumors in relation to normal breast tissue. ${ }^{11}$ 
The FDA-approved near-infrared fluorescent dye, indocyanine green (ICG), is a small synthetic molecule ( $818 \mathrm{Da})$ commonly used as a vascular contrast agent. ${ }^{12}$ The nearinfrared absorption and fluorescence of ICG $(\sim 800 \mathrm{~nm})$ and its rapid clearance from the blood make it an advantageous probe for use in clinical imaging applications. ICG has a dynamic optical absorption spectrum that shifts in peak optical absorption (between 750 and $850 \mathrm{~nm}$ ) depending on various conditions. ${ }^{9}$ Once conjugated to peptides/proteins, the peak optical absorption is approximately $750 \mathrm{~nm} .{ }^{13}$ However, protein-conjugated ICG goes through an intracellular degradation pathway resulting in a characteristic red spectral shift in optical absorption $(\sim 850 \mathrm{~nm}),{ }^{13}$ allowing for highly sensitive and specific identification of targeting protein conjugated ICG by sPA imaging based on molecularly specific cellular uptake of the dye. ${ }^{9}$ Therefore, conjugation of ICG with a ligand specific to breast cancer cell biomarker may be an optimal contrast agent for sPA imaging.

Previously, antibody-based contrast agents have been shown to be useful for molecular imaging. ${ }^{9}, 14,15$ However, monoclonal antibodies have several limitations including long circulation half-lives causing high background imaging signal, nonspecific conjugation or complex specific conjugation, high production costs for widely used cancer screening methods, and elicitation of nonspecific immune response in humans. ${ }^{14,16}$ Smaller proteins against tumor-specific biomarkers for molecular imaging may be advantageous due to their short circulation life, increased stability, and reduced production costs. ${ }^{17-20}$ For example, highly specific antibody fragments $(\mathrm{scFv}, 28 \mathrm{kDa})$ are one potential replacement for full antibodies but are also derived from immunoglobulin backbones. ${ }^{21}$ As monoclonal antibodies and their derivatives are comparatively difficult and expensive to manufacture and have relatively poor heat stability due to their large multidomain structures with complex post-translational patterns, here, we explore the use of affibodies (ABY) as a unique substitute for antibodies in molecular imaging applications. ABY are 58-amino-acid proteins derived from the three-helix bundle $\mathrm{Z}$ domain in Staphyloccocus aureus protein A. ${ }^{22} \mathrm{ABY}$ can be used as scaffolds with phage- or yeast-displayed libraries to selectively engineer binding ligands for the desired molecular target. ${ }^{23,24}$ Compared to antibodies, ABY are smaller in size $(\sim 7 \mathrm{kDa})$, have more simple structures, have high target affinity, exhibit more rapid tumor infiltration, have shorter circulation time, demonstrate greater stability in a wide range of physiological $\mathrm{pH}$ and temperature, are easy to conjugate, and are also cost-effective for large-scale production. ${ }^{22,25-28} \mathrm{ABY}$ molecules have already shown potential for therapeutic, diagnostic, and biotechnological applications. ${ }^{22,29}$

Recently, B7-H3 (CD276), a member of the B7 family of immunoregulators, has been confirmed to be upregulated in ductal carcinoma in situ and all subtypes of invasive breast cancer compared to normal mammary tissues or several subtypes of benign lesions, in both preclinical animal models and clinical human tissue samples. ${ }^{9,30-32}$ B7-H3 is a cell-surface protein expressed in both tumor-associated blood vessels and cancer cells and shows promise as an attractive marker for developing an ABY-based exogenous contrast agent for the detection of breast cancer with sPA imaging.

The purpose of this study was to analyze the feasibility of a clinically translatable B7-H3 targeting ABY-ICG conjugate contrast agent for breast cancer detection by SPA molecular imaging. In this work, we conjugate a recently designed ABY ligand for murine and human 


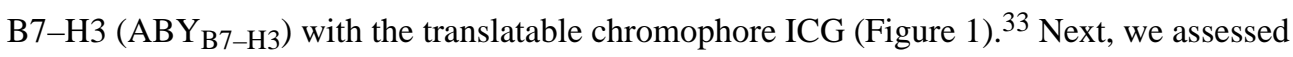
the in vivo dynamics of $\mathrm{ABY}_{\mathrm{B} 7-\mathrm{H} 3}-\mathrm{ICG}$ for sPA molecular imaging in a transgenic mouse model of breast cancer by biodistribution, time-point, and dosage studies. Finally, the specificity and sensitivity of $\mathrm{ABY}_{\mathrm{B} 7-\mathrm{H} 3}-\mathrm{ICG}$ combined with $\mathrm{SPA}$ molecular imaging were determined in malignant breast tissues compared to normal mammary glands in vivo. In light of recent developments and testing of combined PA/US imaging systems for clinical use, $\mathrm{ABY}_{\mathrm{B} 7-\mathrm{H} 3}-\mathrm{ICG}$ may be a reliable contrast agent for human breast cancer detection. 34-36

\section{RESULTS}

\section{Affibody Production and Binding to B7-H3.}

A yeast display library expressing ABY variants on its surface was recently screened to identify variants with B7-H3 antigen binding. ${ }^{33}$ The lead ABY, termed AC2 in the discovery manuscript and herein called $\mathrm{ABY}_{\mathrm{B} 7-\mathrm{H} 3}$, has $310 \pm 80 \mathrm{nM}$ affinity for human B7-H3. 33

$\mathrm{ABY}_{\mathrm{B} 7-\mathrm{H} 3}$ was expressed in $E$. coli and effectively purified by chromatographic separation process (data not shown). Similarly, a scrambled ABY ( ABY $\left._{S C R}\right)$ was produced as a control (sequence provided in Supporting Information file). Mass spectrometry analyses of the

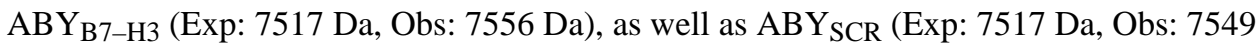
$\mathrm{Da})$, assessed molecular weight and high purity of these recombinantly produced peptides (Figure 2A and Figure S1A). Next, binding activity of $\mathrm{ABY}_{\mathrm{B} 7-\mathrm{H} 3}$ to its target expressed on cells was determined by flow cytometry. Upon conjugation of $\mathrm{ABY} \mathrm{B}_{\mathrm{B}-\mathrm{H} 3}$ with biotin via free primary amines, $\mathrm{ABY} \mathrm{B}_{\mathrm{B} 7-\mathrm{H} 3}$ effectively maintains specific activity as it binds MS1 cells overexpressing human $\mathrm{B} 7-\mathrm{H} 3\left(\mathrm{MS}_{\mathrm{B} 7-\mathrm{H} 3}\right)$ but not parental MS1 cells that lack $\mathrm{B} 7-\mathrm{H} 3$ (MS1 $1_{\text {wild-type }}$ ) as detected by streptavidin Alexa Fluor 647 dye signal (Figure S2A). $\mathrm{ABY}_{\mathrm{B} 7-\mathrm{H} 3}$ binding signal was comparable to that of an APC dye conjugated anti-B7-H3 antibody binding to cells. In comparison, the $\mathrm{ABY}_{\mathrm{SCR}}$ showed minimal nonspecific binding to all cell types at the tested concentration of $1 \mu \mathrm{M}$ (Figure S2A,B). ABY $\mathrm{B}_{\mathrm{B}-\mathrm{H} 3}$ also bound to the mouse monocyte cell line, RAW264.7, expressing the murine isoform of B7-H3 (Figure S2B).

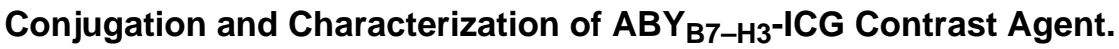

Expressed $\mathrm{ABY}_{\mathrm{B} 7-\mathrm{H} 3}$ was conjugated on free amines to ICG dye via $N$ hydroxysuccinimidyl ester chemistry to produce the $\mathrm{ABY}_{\mathrm{B} 7-\mathrm{H} 3}-\mathrm{ICG}$ contrast agent for sPA imaging. Characterization of $\mathrm{ABY}_{\mathrm{B} 7-\mathrm{H} 3}$ was carried out using spectrophotometry and SDSPAGE to confirm its purity and ICG conjugation. The absorption of the ABY $\mathrm{B}_{-\mathrm{H} 3}-\mathrm{ICG}$ and $\mathrm{ABY}_{\mathrm{SCR}^{-}} \mathrm{ICG}$ at 280 and $800 \mathrm{~nm}$, corresponding to the protein and dye peaks, respectively, were measured with a spectrophotometer (Figures 2B and S1B) and used to calculate the average binding ratio of 1.0 ICG per ABY. SDS-PAGE analysis and fluorescence imaging for confirmed its correct molecular weight $(\sim 7.5 \mathrm{kDa})$, high purity of expressed peptide, and stable ligand conjugation of the ICG with $\mathrm{ABY}_{\mathrm{B} 7-\mathrm{H} 3}$ (Figure $2 \mathrm{C}$ ). The peptide band corresponding to the $\mathrm{ABY} \mathrm{B}_{\mathrm{B}-\mathrm{H} 3}-\mathrm{ICG}$ contrast agent confirms associated ICG signal in the fluorescence mode and lacks the presence of free unconjugated dye after the purification steps. 


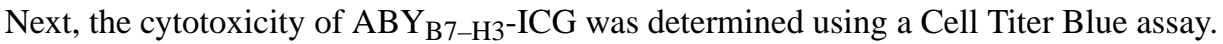
Incubation of a human breast cancer cell line expressing B7-H3, MDA-MB-231 cells, ${ }^{37}$ with $\mathrm{ABY}_{\mathrm{B} 7-\mathrm{H} 3}-\mathrm{ICG}$ at $0-600 \mathrm{ng} / \mathrm{mL}(0-80 \mathrm{nM})$ for $24 \mathrm{~h}$, did not cause toxicity to cells as evidenced by maintained cell viability (Figure 2D). Next, the intracellular fate of $\mathrm{ABY}_{\mathrm{B} 7-\mathrm{H} 3}$ was assessed via an in vitro cellular uptake assay with confocal imaging. $\mathrm{ABY}_{\mathrm{B} 7-\mathrm{H} 3}$ conjugated to a fluorescent dye (AF633) displayed a higher degree of intracellular colocalization within the lysosomes of $\mathrm{MS} 1_{\mathrm{B} 7-\mathrm{H} 3}$ cells after $1 \mathrm{~h}$ of incubation compared to the MS1 $1_{\text {Wild-type }}$ cells. In addition, $\mathrm{ABY}_{\mathrm{B} 7-\mathrm{H} 3 \text {-associated } \mathrm{AF} 633 \text { staining was also observed }}$ on the cell surface of $\mathrm{MS}_{\mathrm{B} 7-\mathrm{H} 3}$ cells (Figure 2E).

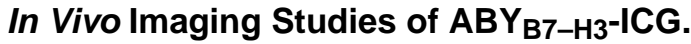

Biodistribution of $A B Y_{B 7-H 3}-I C G$. In order to quantify in vivo localization of contrast agent, the biodistribution of $\mathrm{ABY}_{\mathrm{B} 7-\mathrm{H} 3}-\mathrm{ICG}$ was examined via fluorescence imaging in a transgenic (MMTV-PyMT) murine model of breast cancer. Accumulation of $\mathrm{ABY}_{\mathrm{B} 7-\mathrm{H} 3^{-}}$ ICG within the mammary tissues ( 10 glands/mouse; $n=20$ glands/group) at different time points was visually assessed in tumor-bearing and transgene negative control mice at $0,2,4$, 8,24 , and $48 \mathrm{~h}$ post intravenous tail vein injection of $33 \mu \mathrm{g}$ of $\mathrm{ABY}_{\mathrm{B} 7-\mathrm{H} 3}-\mathrm{ICG}$ by live animal fluorescence imaging (Figure 3A). Fluorescence signal from ICG was predominantly observed in the liver and abdominal area for both $\mathrm{ABY}_{\mathrm{B} 7-\mathrm{H} 3}-\mathrm{ICG}$ and $\mathrm{ABY}_{\mathrm{SCR}}-\mathrm{ICG}$ (Figure 3A and Figure S3). At $8 \mathrm{~h}$ (1.8 \pm 0.4 -fold increase), $24 \mathrm{~h}$ (1.9 \pm 0.3 -fold increase), and $48 \mathrm{~h}$ (1.7 \pm 0.4 -fold increase), mammary glands of tumor-bearing mice showed a significantly larger increase in radiant efficiency compared to the signal levels before administration of contrast agent. Tumor negative control mice did not show significant increase in fluorescence signal in mammary glands ( $8 \mathrm{~h}: 1.1 \pm 0.2$-fold; $24 \mathrm{~h}: 1.2 \pm 0.1$-fold; and $48 \mathrm{~h}: 1.0 \pm 0.03$-fold). The difference between the mammary tumor signals compared to normal glands was significant ( $p<0.05$ ) at 8,24 , and $48 \mathrm{~h}$ time-points (Figure 3B).

$\mathrm{ABY}_{\mathrm{B} 7-\mathrm{H} 3}$-ICG fluorescence signal increased in both mammary tumors and normal glands initially $(2-4 \mathrm{~h})$ with no statistically significant difference, but the signal remained significantly $(p<0.05)$ elevated in tumors only at later time-points $(8-48 \mathrm{~h})$. The $\mathrm{ABY}_{\mathrm{SCR}^{-}}$ ICG -associated fluorescence signal also increased in tumors at $24 \mathrm{~h}$ time-point $(1.4 \pm 0.3$ fold) (Figure $\mathrm{S} 3$ ). $\mathrm{ABY}_{\mathrm{B} 7-\mathrm{H} 3}-\mathrm{ICG}$ signal in liver and bowel peaked in the control mice at the $2 \mathrm{~h}$ time-point, while the liver signal in mice with tumor burden peaked at the $4 \mathrm{~h}$ time-point and bowel signal peaked at $8 \mathrm{~h}$ post injection (Figure 3C).

Ex vivo imaging confirmed the live animal imaging observation of $\mathrm{ABY}_{\mathrm{B} 7-\mathrm{H} 3}-\mathrm{ICG}$ accumulation within mammary glands of tumor-bearing and transgene negative control mice at $24 \mathrm{~h}$ post administration of contrast agent. Extracted mammary tissue from tumor-bearing mice showed higher fluorescence signal (2.2-fold background signal) than the normal mammary glands (0.9-fold background signal) (Figure 3A).

\section{Minimum Dosage and Optimal Timing of $A B Y_{B 7-H 3-I C G}$ Injection for Tumor sPA and Fluorescence Imaging.}

Dosage and time-point optimization of the novel $\mathrm{ABY}_{\mathrm{B} 7-\mathrm{H} 3-\mathrm{ICG} \text { contrast agent was }}$ determined through in vivo sPA and fluorescence imaging studies in the same murine model system. To determine an optimized dosage of $\mathrm{ABY}_{\mathrm{B} 7-\mathrm{H} 3}-\mathrm{ICG}, \mathrm{sPA}$ contrast signal was 
quantified in breast tumors and normal mammary glands $24 \mathrm{~h}$ after injection of 20,33, or 50 $\mu \mathrm{g}$ dosages. $33 \mu \mathrm{g}$ showed statistically significant signal increase relative to preinjection levels: $2.4 \pm 0.9$-fold $(p<0.05)$ with sPA imaging and a $1.8 \pm 0.4$-fold $(p<0.05)$ with fluorescence imaging (Figure 4A,B). While the $50 \mu \mathrm{g}$ dosage also shows a significant increase of $2.5 \pm 1.3$-fold $(p<0.05)$ with sPA imaging and $2.2 \pm 0.2$-fold $(p<0.05)$ with fluorescence imaging, these mice also show the highest abdominal signal and noise associated with fluorescence in the liver and bowels, which interfered with signal quantification from tumors, especially in the mammary glands closest to the liver.

After determination of the optimal dosage as $33 \mu \mathrm{g}$, tumor-bearing and transgene-negative control mice were imaged for sPA signal at different time points $(0,2,4,8,24$, and $48 \mathrm{~h})$ to specify an optimal imaging time post $\mathrm{ABY}_{\mathrm{B} 7-\mathrm{H} 3}-\mathrm{ICG}$ administration. Tumor-positive mice showed significant $(p<0.05)$ increase in sPA signal at $8 \mathrm{~h}(1.8 \pm 0.5$-fold $), 24 \mathrm{~h}(2.4 \pm 0.9$ fold), and $48 \mathrm{~h}$ ( $2.2 \pm 1.4$-fold) from tumors compared to before administration of contrast agent (Figure 4C,D). Tumor negative control mice showed no significant increase in B7-H3associated sPA signal from mammary glands for any of the imaging time points. At 8, 24, and $48 \mathrm{~h}$, the sPA signal in tumors were significantly higher $(p<0.05)$ compared to those in the normal glands (sPA images not shown, quantified in Figure 4D). Thus, effective sPA imaging is achievable from $8-48 \mathrm{~h}$ post-injection.

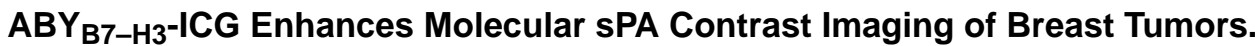

Following in vivo optimization of imaging parameters, we evaluated molecular sPA and fluorescence imaging signal of $\mathrm{ABY}_{\mathrm{B} 7-\mathrm{H} 3}-\mathrm{ICG}$ for specificity to $\mathrm{B} 7-\mathrm{H} 3$ expression in breast tumors. Normal glands served as tissue controls for tumors, while the blocking group and

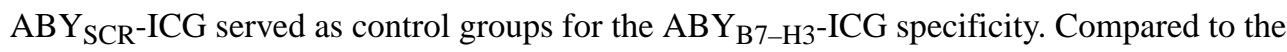
imaging signal prior to administration of contrast agent, glands containing invasive carcinomas from mice injected with $\mathrm{ABY}_{\mathrm{B} 7-\mathrm{H} 3}-\mathrm{ICG}$ showed a 2.1 \pm 1.2 -fold increase in molecular B7-H3 signal with sPA imaging and a $1.6 \pm 0.4$-fold increase with fluorescence imaging after $24 \mathrm{~h}$ (Figure 5A,B). Normal mice injected with $\mathrm{ABY}_{\mathrm{B} 7-\mathrm{H} 3-\mathrm{ICG} \text { did not }}$ increase sPA or fluorescence imaging signal (sPA: $1.1 \pm 0.5$-fold; fluorescence: $1.0 \pm 0.4$ fold) in mammary glands after $24 \mathrm{~h}$, which were significantly $(p<0.05)$ lower than those of the tumor group. Compared to the tumor imaging group, mice with blocked $\mathrm{B} 7-\mathrm{H} 3$ receptor by injecting $100 \mu \mathrm{g}$ non-conjugated $\mathrm{ABY}_{\mathrm{B} 7-\mathrm{H} 3} 24 \mathrm{~h}$ prior to injection with $\mathrm{ABY}_{\mathrm{B} 7-\mathrm{H} 3-\mathrm{ICG}}$ showed significant reduction in SPA signal $(1.0 \pm 0.4$-fold; $p<0.05)$ but not the fluorescence imaging signal (1.5 \pm 0.4 -fold). In addition, blocking group fluorescence signal but not the sPA signal was significantly higher $(p<0.05)$ than that of the normal glands. The $\mathrm{ABY}_{\mathrm{SCR}^{-}}$ ICG group imaging signal of tumors (sPA: $1.1 \pm 0.6$-fold; fluorescence: $1.4 \pm 0.3$-fold) at 24 $\mathrm{h}$ time point was significantly lower than the sPA signal $(p<0.05)$ from the tumor group with $\mathrm{ABY}_{\mathrm{B} 7-\mathrm{H} 3}-\mathrm{ICG}$ but the fluorescence imaging signals from both contrast agents were comparable (Figure 5A,B).

\section{B7-H3 Expression in Murine Breast Cancer.}

Finally, normal mammary glands and invasive breast tumors were extracted from the transgenic mice after imaging and validated for $\mathrm{B} 7-\mathrm{H} 3$ expression by immunofluorescence staining of tissue sections. Anti-B7-H3 antibody staining showed expression of B7-H3 by 
breast cancer cells as well as tumor vasculature (CD31 and B7-H3 double-positive areas) in breast tumors compared to normal mammary glands (Figure S4).

\section{DISCUSSION}

In this work, we undertook several steps to develop a clinically translatable contrast agent specific to the $\mathrm{B} 7-\mathrm{H} 3$ marker for sPA and fluorescence molecular imaging of murine breast cancer. First, the engineered $\mathrm{ABY}$ ligand $\left(\mathrm{ABY}_{\mathrm{B} 7-\mathrm{H} 3}\right)$, upon biotin conjugation, was shown to specifically bind to both human and mouse B7-H3 expressing cells in a flow cytometry based in vitro study. Furthermore, conjugation of $\mathrm{ABY}$ to a fluorescent dye enabled direct visualization of cellular uptake and lysosomal compartmentalization mainly in the B7-H3 expressing cells. Next, ICG, a near-infrared fluorescence dye, was conjugated to the ABY to

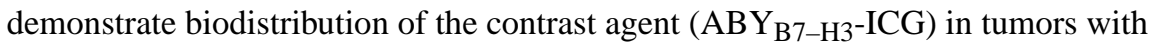
fluorescence imaging. sPA imaging was used to optimize molecular signal representative of B7-H3 expression in mammary tumors compared to normal mammary glands in a dosage and time-point dependent manner of contrast agent administration. Finally, a multicontrol in vivo imaging study demonstrated the ability of sPA molecular imaging to detect $\mathrm{ABY}_{\mathrm{B} 7-\mathrm{H}^{-}}$ ICG in mammary cancer with higher specificity and sensitivity compared to fluorescence imaging.

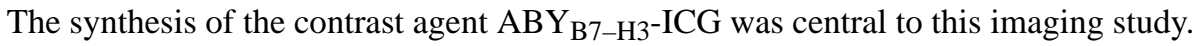
Spectrophotometry analysis of the bioconjugate showed both protein and ICG associated absorption peaks, each corresponding to individual component absorption analyses. SDS gel and its fluorometric scan confirmed several important aspects of a successful bioconjugation: correct size and high purity of the recombinantly produced ABY, fluorescence signal associated with ABY bound ICG dye, and trace amount of free dye after the contrast agent formulation and purification.

The pathway of dye conjugated ABY internalization is important for the selection of sPA optical probes to detect the signal of contrast agent uptake by cancer cells in the tumors. Cellular uptake assay showed high $\mathrm{ABY}_{\mathrm{B} 7-\mathrm{H} 3}$ binding to the surface of $\mathrm{MS}_{\mathrm{B} 7-\mathrm{H} 3}$ cells and internalization to lysosomal compartments by confocal microscopy. Lysosomal degradation of $\mathrm{ABY}_{\mathrm{B} 7-\mathrm{H} 3}-\mathrm{ICG}$ conjugate and the release of ICG alters its spectral properties, allowing capture of a highly specific B7-H3 signal by sPA imaging. ${ }^{9}$ This mechanism of $A B Y_{B} 7-\mathrm{H} 3$ internalization combined with translatable dyes such as ICG are highly desirable for molecularly targeted imaging methods in vivo. ${ }^{38}$ In addition, $\mathrm{ABY}_{\mathrm{B} 7-\mathrm{H} 3}$ binds to both mouse and human B7-H3 isoforms. Since the extracellular portion of B7-H3 from both species share close homology, ${ }^{39}$ it makes $\mathrm{ABY}_{\mathrm{B} 7-\mathrm{H} 3}$ a suitable probe for both studies in mice as well as further development for human use.

As ICG is rapidly cleared from blood into liver, ${ }^{40}$ we investigated the biodistribution

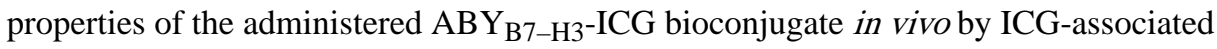
fluorescence imaging. The biodistribution study demonstrated the agent's significant accumulation in mammary glands of tumor positive transgenic mice as early as $8 \mathrm{~h}$ compared to those of control healthy mice. Fluorescence signal in tumors and normal mammary glands at 2 and $4 \mathrm{~h}$ represent background blood pool signal. In addition, the liver 
and bowels of mice showed high fluorescence signal up to the $24 \mathrm{~h}$ time-point. Signal in the liver and bowels of mice may be due to the known hepatobiliary excretory pathway of ICG.

${ }^{40}$ It is noteworthy that the peak fluorescence signal in liver and bowel of control mice at the earliest time-point, $2 \mathrm{~h}$, compared to tumor-bearing mice suggests that the contrast agent is rapidly metabolized in the absence of its target. Rapid biodistribution and high tissue

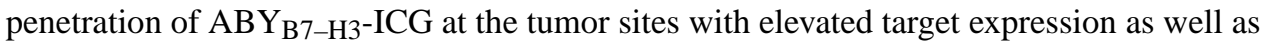
fast clearance of unbound $\mathrm{ABY}$ and ICG shows promise for contrast enhanced tumor

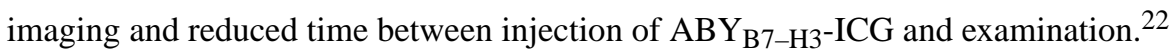

Due to the novel nature of the contrast agent, the dosage and timing of this contrast agent required optimization for in vivo sPA and fluorescence imaging. First, the minimum dosage of contrast agent needed for significant increase in SPA signal in tumors was determined. This is an important consideration in this small animal model as the ten mammary glands are proximal to the noted background abdominal signal which may interfere with imaging results. In clinical settings, minimal dosage reduces the amount of foreign substance administered to the patient, reducing costs and minimizing background signal. The use of 33 $\mu \mathrm{g}$ of contrast agent and imaging $24 \mathrm{~h}$ post administration were optimal for imaging purposes and mice did not show any apparent side-effects. The $50 \mu \mathrm{g}$ dosage of contrast agent also enabled effective sPA imaging signal in tumors; however, the high fluorescence signal in the abdominal area interfered with signal quantification in the nearby mammary tumors. The $33 \mu \mathrm{g}$ dose (approximately $1.65 \mathrm{mg} / \mathrm{kg}$ ) in mouse represents a significantly smaller dose $\left(0.13 \mathrm{mg} / \mathrm{kg}\right.$ in humans $\left.{ }^{41}\right)$ than what is traditionally used for therapeutic antibodies (up to $12.5 \mathrm{mg} / \mathrm{kg}$ in human serum ${ }^{42}$ ) and toxicity limits of ABY-drug conjugates in mice. ${ }^{43} \mathrm{~A}$ recent toxicological study of anti-EGFR ABY conjugated to a near-infrared dye, IRDye $800 \mathrm{CW}$, produced no pathological evidence of toxicity up to $24 \mathrm{mg} / \mathrm{kg}$ in rat models of glioma, suggesting safe and tolerable use of engineered ABY protein-based agents in the ongoing human clinical trials. ${ }^{44,45}$

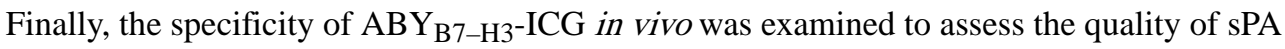

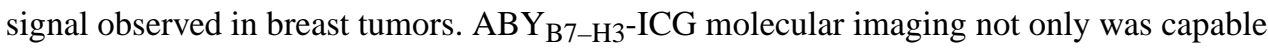
of differentiating breast tumors from the healthy mammary tissues, but also showed high specificity to its target, the B7-H3 receptor, in vivo. Injection of unconjugated ABY for $24 \mathrm{~h}$ to saturate tumor localized $\mathrm{B} 7-\mathrm{H} 3$ receptors prior to administration of $\mathrm{ABY}_{\mathrm{B} 7-\mathrm{H} 3}-\mathrm{ICG}$ significantly reduced SPA signal in breast tumors compared to the group without ABY blocking. In contrast, the blocking study was able to show only a nonsignificant reduction in fluorescence signal from tumors after receptor blocking. This particular observation highlights the ability of sPA molecular imaging to differentiate between molecularly bound and internalized agent and that which is nonspecifically accumulated in tumor tissues via changes in optical absorption spectrum that occur during cellular internalization. ${ }^{9}$ Similarly, the administration of a $\mathrm{ABY}_{\mathrm{SCR}}-\mathrm{ICG}$ contrast agent did not increase sPA signal within the tumor but moderately increased fluorescence signal, which suggests that nontargeted peptides are also able to passively diffuse into the tumor interstitial space through enhanced permeability and retention effects, but only sPA is capable of suppressing imaging signal from nonspecific accumulation. ${ }^{46}$ Although in vivo photobleaching can be a concern for sPA signal acquisition, this was not observed due to constant accumulation of contrast agent in the tumors and the use of low laser fluence during sPA imaging. In our experiments, sPA 
signal but not the fluorescence signal was able to distinguish in vivo B7-H3 molecular specificity of $\mathrm{ABY}$ between $\mathrm{ABY}_{\mathrm{B} 7-\mathrm{H} 3}$ and $\mathrm{ABY}_{\mathrm{SCR}}$. The sPA signal enhancement with $\mathrm{ABY}_{\mathrm{B} 7-\mathrm{H} 3}$ was also similar between independently executed dosage, time-point, and molecular imaging experiments suggesting reproducibility of B7-H3 sPA signal in mammary tumors. Fluorescence signal obtained with targeted contrast agents without the use of a spectroscopic algorithm examining endocytosis mediated absorption changes may inaccurately represent the molecular expression of biomarkers in breast tumors. ${ }^{46}$ Therefore, sPA molecular imaging was effectively more specific and sensitive than fluorescence imaging, which cannot detect these changes in this application. Although blocking in vivo is a subjective measure of ABY target specificity, it suggests that the molecular sPA signal from the tumor corresponds mainly to high $\mathrm{B} 7-\mathrm{H} 3$ expression by cancer cells. This interpretation is corroborated by the fact that $\mathrm{ABY}_{\mathrm{SCR}}-\mathrm{ICG}$ did not produce significantly high sPA signal enhancement in the mammary tumors. Expression of the target was validated by immunofluorescence staining of extracted breast tissue sections, which stained positive for B7-H3 but was absent in normal mammary glands. B7-H3 was expressed by both epithelial and endothelial components of breast tumors. 9,30

These experiments show that ABYs can substitute for antibodies as targeting moieties in contrast agents for sPA and fluorescence imaging with potentially significant advantages in clinical applications. While monoclonal antibodies are commonly used as affinity proteins for targeted therapeutics, they have long in vivo half-lives and slow blood-clearance in humans, taking several days for background contrast signal to disappear before a sensitive molecular imaging can be performed at the site of interest. ${ }^{47}$ Due to the long half-lives of antibody molecules, the risks of immune response may increase even in the humanized derivatives of monoclonal antibodies. ${ }^{48}$ Target specific small peptide ligands, such as ABY, are promising alternatives to antibodies for use as imaging contrast agents in clinical applications as they can be engineered to suit a variety of specifications such as low molecular weight, fast blood clearance, and nanomolar ligand-binding affinity. ABY are also suitable for cost-effective production at scale for screening and diagnostic imaging needs.

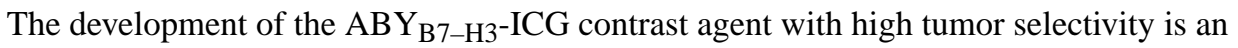
important step toward clinical translation of PA and fluorescence molecular imaging for early detection of breast cancer.

Previous studies have demonstrated that B7-H3 (CD276) is differentially expressed in clinical breast cancer with abundant endothelial and epithelial expression. ${ }^{9,30,32}$ The abundant expression of this target on the extravascular compartment is optimal for PA and

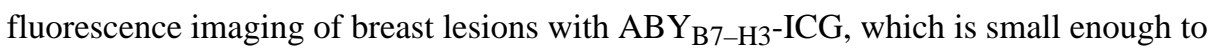
extravasate into tumor interstitial spaces. In addition, the B7-H3 targeted contrast agent maintained both sPA and fluorescence signal in tumors throughout the time point study for tumor bearing mice compared to the transgene negative control mice. The optimal accumulation is demonstrated within $24 \mathrm{~h}$ of contrast agent administration, ideal for clinical applications.

Mammographically detected lesions for dense breasts usually tend to be larger or higher grade, ${ }^{49}$ partly due to low imaging sensitivity of mammography for this subgroup of patients at earlier screening time-points. The newly developed molecular contrast agent may aid in 
breast cancer detection and disease management with PA imaging, especially in women with mammographically dense breasts. Clinical PA imaging systems combine the high sensitivity of optical imaging and the deep-tissue penetration of ultrasonic imaging to create high contrast and high resolution images. ${ }^{50}$ As the bioconjugation of ICG to the ABY allowed relative B7-H3 expression to be compared at cellular levels and produce reliable molecular sPA signature of tumors, its combination will further improve the quality of sPA signal, especially for deep clinical imaging of dense breasts. Other clinical scenarios involving intraoperative resection, targeted-drug administration, therapy monitoring, and tumor visualization will also benefit based on SPA imaging with B7-H3-targeted contrast agents. 31,51

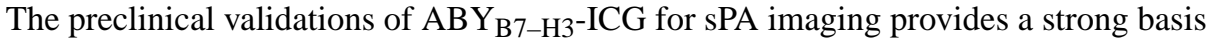
toward its use in clinical breast cancer screening and diagnostics; however, there is also room for improvement in many aspects including ligand affinity, bioconjugate aggregation, preclinical image analysis, and molecular target confirmation in patients with mammographically dense breasts. During the conclusion and publication of our study, $\mathrm{ABY}_{\mathrm{B} 7-\mathrm{H} 3}$ was evolved for elevated affinity $\left(K_{\mathrm{d}}=0.9 \pm 0.6 \mathrm{nM}\right)$ and stability $\left(T_{\mathrm{m}}=61.5\right.$ $\left.\pm 0.1{ }^{\circ} \mathrm{C}\right) .{ }^{33}$ Although our current bioconjugate incorporates one ICG per molecule of ABY, a mechanistic investigation of ABY and ICG interaction is needed to study ICG aggregationor concentration-dependent changes in PA signal intensity from the contrast agent. ${ }^{52,53}$ Future work will examine the impact of these improvements in the context of molecular imaging. Second, in the current study, image analysis and in vivo spectral-unmixing of photoacoustic signal was performed by in-house scripts, ${ }^{9,31}$ which could be improved by implementing machine learning-based approaches. Currently, sPA algorithms use simple linear regression between detected sPA signals to known optical absorption of the chromophores of interest. Machine learning algorithms may better recognize $\mathrm{ABY}_{\mathrm{B} 7-\mathrm{H} 3-}$ ICG patterns found in data increasing classification accuracy. More accurately extracting

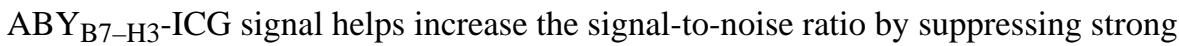
background signal from hemoglobin (the dominant photoabsorber in tissue) and will increase the sensitivity of sPA imaging to the highly specific B7-H3 breast cancer marker. Third, the transgenic mouse model utilized in this report spontaneously develops tumors in mammary glands and results in invasive cancer with high B7-H3 expression. We were unable to highlight the superior PA imaging depth with the targeted probe in comparison to fluorescence imaging in this mouse model, although SPA probe signal could be measured efficiently up to $1-2 \mathrm{~cm}$. Also, there are no mouse models available that can correlate disease pathogenesis in the context of dense breast tissue since the stromal compartment of mammary glands in rodents is different from that of humans. Instead, clinical investigations on the association of breast density with tissue marker-defined breast cancer subtypes can clarify the relevance of molecularly targeted sPA imaging in patients with hard-to-diagnose breasts. One such study demonstrated stronger associations in estrogen receptor-negative tumors with percent density in breasts; ${ }^{54}$ however, further studies are warranted to elucidate the role of markers such as B7-H3 in associating high breast density to the specific subtypes of breast carcinomas. These etiological analyses would help identify mammographically dense breast cases to be recommended for supplemental imaging methods involving sPA molecular imaging. 
We engineered a bioconjugate of an $\mathrm{ABY}$ and fluorescent dye-based contrast agent that can differentiate between diseased and healthy mammary tissue by sPA imaging in a mouse model of breast cancer with strong potential for clinical translation. Advancement of this inexpensive and translatable photoacoustic contrast agent into the clinical arena may complement second-line imaging modalities such as US imaging 55 for accurate detection and characterization of malignant lesions in women with mammographically dense breasts without invasive interventions.

\section{MATERIALS AND METHODS}

\section{Recombinant Production of Engineered B7-H3 Specific Affibody.}

A pET24b plasmid containing the gene encoding $\mathrm{ABY}_{\mathrm{B} 7-\mathrm{H} 3}$ with a C-terminal His 6 tag was transformed into BL21 E. coli and grown in $10 \mathrm{~mL}$ lysogeny broth supplemented with 50 $\mathrm{ng} / \mathrm{mL}$ kanamycin overnight. The outgrowth media was transferred to $250 \mathrm{~mL}$ lysogeny broth with kanamycin and incubated until the optical density $\left(\mathrm{OD}_{600}\right)$ reached between 0.4 and $0.8 \mathrm{~cm}^{-1}$. Induction was performed with $400 \mu \mathrm{M}$ isopropyl $\beta$-D-1-thiogalactopyranoside for $5 \mathrm{~h}$, and cells were lysed by sonication in lysis buffer (1 M monosodium phosphate (pH 8.0), $1 \mathrm{M}$ disodium phosphate, $5 \mathrm{M}$ sodium chloride, 5\% glycerol, 3-[(3-cholamidopropyl) dimethylammonio]-1-propanesulfonate, $25 \mathrm{mM}$ imidazole, and a dissolved tablet/10 $\mathrm{mL}$ of EDTA free protease inhibitor) (ThermoScientific). The sonicated cells were centrifuged at $12,000 \times g$ for $10 \mathrm{~min}$ to remove the insoluble fraction. Supernatant was purified and eluted by fast protein liquid chromatography using a Histrap FF Crude $1 \mathrm{~mL}$ column (GE Healthcare) in PBS with $200 \mathrm{mM}$ imidazole. ABY was then desalted and washed thrice in PBS using $3 \mathrm{kDa}$ molecular weight cutoff filters (GE Healthcare) centrifuged at $12,000 \times g$ for 20 min each. Protein concentration (A280) of the protein was determined by NanoDrop (ThermoScientific). Protein was stored in $4{ }^{\circ} \mathrm{C}$ until use within 1 week. Similarly, a control scrambled $\mathrm{ABY}\left(\mathrm{ABY}_{\mathrm{SCR}}\right)$ with no known target specificity was expressed. Matrix-assisted laser desorption ionization time-of-flight (MALDI-TOF) mass spectrometry analysis was performed to confirm the size and purity of recombinantly produced $\mathrm{ABY}$.

\section{Cell Culture.}

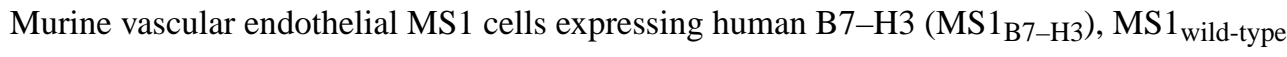
cells, murine monocyte cell line, RAW264.7, and human breast cancer cell line, MDAMB-231, were grown in DMEM supplemented with 10\% fetal bovine serum and 1\% penicillin-streptomycin.

\section{Flow Cytometry Determination of $\mathrm{ABY}_{\mathrm{B} 7-\mathrm{H} 3}$ Binding to Human and Mouse B7-H3.}

For B7-H3 expression analysis, 1 million MS1 $1_{\text {wild-type }}, \mathrm{MS} 1_{\mathrm{B} 7-\mathrm{H} 3}$, and RAW264.7 cells were washed in PBS containing 0.5\% BSA and incubated with APC-conjugated goat antihuman B7-H3 antibody (R\&D Systems) or rabbit anti-mouse B7-H3 antibody (Abcam) at $4{ }^{\circ} \mathrm{C}$ for $1 \mathrm{~h}$. The APC-anti-rabbit secondary antibody (Abcam) was used to detect antimouse B7-H3 antibody. Cells were washed by centrifugation and analyzed in BD FACS Aria III. Data analysis was performed in Flow Jo 2.0. 
For ABY binding to MS1 or RAW264.7, cells were incubated with biotinylated $\mathrm{ABY}_{\mathrm{B} 7-\mathrm{H} 3}$ or $\mathrm{ABY}_{\mathrm{SCR}}$ for $1 \mathrm{~h}$ at $4{ }^{\circ} \mathrm{C}$. Cells were washed in PBS containing $0.5 \% \mathrm{BSA}$ and incubated with streptavidin-Alexa Fluor 647 dye for $30 \mathrm{~min}$, washed, and analyzed for binding to cells by flow cytometry.

\section{Synthesis and Characterization of the $A B Y_{B 7-H 3}-I C G$ Contrast Agent.}

Immediately prior to each imaging session, fresh $\mathrm{ABY}_{\mathrm{B} 7-\mathrm{H} 3}-\mathrm{ICG}$ and control contrast agents were prepared as follows. Indocyanine green (ICG)-N-hydroxysuccinimide (NHS) (Intrace Medical Co.) was conjugated to $\mathrm{ABY}_{\mathrm{B} 7-\mathrm{H} 3}$ via NHS ester labeling of primary amines on the $\mathrm{ABY}$. $\mathrm{ABY}_{\mathrm{B} 7-\mathrm{H} 3}-\mathrm{ICG}$ conjugation was carried out with $1 \mathrm{M}$ sodium bicarbonate buffer $(\mathrm{pH} 8.3)$ and shaken at room temperature for $2 \mathrm{~h}$ protected from light. The reaction mixture contained $100 \mu \mathrm{g}$ of $\mathrm{ABY}_{\mathrm{B} 7-\mathrm{H} 3}, 50 \mu \mathrm{L}$ of sodium bicarbonate buffer, and 10 times the molar equivalent of ICG to $\mathrm{ABY}_{\mathrm{B} 7-\mathrm{H} 3}(108 \mu \mathrm{g})$. Free ICG dye was removed using $0.5 \mathrm{~mL}$ Zeba Spin Desalting Columns with a $7 \mathrm{kDa}$ molecular weight cutoff filter (ThermoScientific).

For contrast agent characterization, several assays were undertaken. First, the absorption of

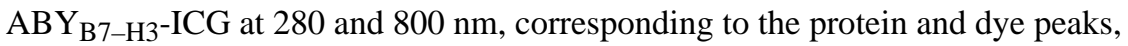
respectively, were measured with a spectrophotometer (Nano-Drop). Using the molar extinction coefficients of ICG at $800 \mathrm{~nm}\left(\varepsilon_{\text {Dye }}=22,884 \mathrm{~L} / \mathrm{mol}^{*} \mathrm{~cm}\right)$, the molar extinction coefficient of the $\mathrm{ABY}_{\mathrm{B} 7-\mathrm{H} 3}\left(\varepsilon_{\text {Protein }}=8480 \mathrm{~L} / \mathrm{mol}^{*} \mathrm{~cm}\right)$, and a correction factor of 0.07 for the mild ICG absorption at $280 \mathrm{~nm}$, the ICG/ABY ${ }_{\mathrm{B} 7-\mathrm{H} 3}$ ratio was calculated. ${ }^{56}$

Next, SDS-PAGE analysis was performed to confirm purity and stable ligand conjugation of the ICG-NHS ester to the engineered $\mathrm{ABY}_{\mathrm{B} 7-\mathrm{H} 3}$. $\mathrm{ABY}_{\mathrm{B} 7-\mathrm{H} 3}-\mathrm{ICG}$ was loaded onto 4-12\% Tris gel (Novex) and imaged (LI-COR Odyssey FC Scanner) at 700 and $800 \mathrm{~nm}$ to detect the fluorescence from ICG labeled ABY and free ICG. Coomassie blue stain (ThermoScientific) was performed to visualize the labeled and unlabeled resolved protein bands in the gel.

\section{In vitro Cytotoxicity Assay of $\mathrm{ABY}_{\mathrm{B} 7-\mathrm{H} 3}-\mathrm{ICG}$.}

In order to test the possible cytotoxic effects of ICG-ABY bioconjugate, MDA-MB-231 cells were seeded at 50,000 cells/well in a 96 well plate overnight. Next, $\mathrm{ABY}_{\mathrm{B} 7-\mathrm{H} 3-\mathrm{ICG}}$ was added at $6-600 \mathrm{ng} / \mathrm{mL}$ concentration in $100 \mu \mathrm{L}$ of DMEM and incubated for $24 \mathrm{~h}$. Media was aspirated from wells and replaced with $50 \mu \mathrm{L}$ Cell Titer Blue (CTB) redox dye (diluted 1:1 in DMEM). After incubation for $2 \mathrm{~h}$, fluorescence reading of metabolized CTB dye (excitation $560 \mathrm{~nm}$ and emission $590 \mathrm{~nm}$, where fluorescence from ICG is minimal) was performed in microplate reader (Tecan Infinite M1000, ThermoFisher Scientific) to measure the effect of contrast agent on cell viability.

\section{Intracellular Uptake and Localization of $A B Y_{B 7-H 3}$.}

To examine the intracellular pathway of $\mathrm{ABY}_{\mathrm{B} 7-\mathrm{H} 3}-\mathrm{ICG}$ (degradation or recycling), live cell imaging experiments were performed. To be able to visualize the $\mathrm{ABY}$ conjugates using available confocal microscopy filter sets, ICG dye was replaced by Alexa Fluor 633-NHS (AF633) at the same conjugation ratio. Conjugation of $\mathrm{AF} 633$ to $\mathrm{ABY}_{\mathrm{B} 7-\mathrm{H} 3}$ followed the 
same procedure as the ICG conjugation. For $\mathrm{ABY}_{\mathrm{B} 7-\mathrm{H} 3}-\mathrm{AF} 633$ uptake studies, $\mathrm{MS} 1_{\mathrm{B} 7-\mathrm{H} 3}$ and $M S 1_{\text {wild-type }}$ cells were seeded on chambered coverglass culture dishes (Nunc Lab-Tek II Chambered Coverglass) at a density of $5 \times 10^{4}$ cells/dish. On day two of culture, the cells were rinsed with PBS and the media replaced with incubation buffer (serum-free DMEM with $1 \%$ penicillin/streptomycin). To label lysosomes, the cells were incubated with Lysosomes-GFP (LysoTracker Green (Invitrogen), $75 \mathrm{nM}$ ) prior to addition of $\mathrm{ABY}_{\mathrm{B} 7-\mathrm{H} 3^{-}}$ AF633 (5 $\mu \mathrm{g} / \mathrm{dish})$ at $37{ }^{\circ} \mathrm{C}$ for $1 \mathrm{~h}$. After incubation, unbound ABY ${ }_{\mathrm{B} 7-\mathrm{H} 3}-\mathrm{AF} 633$ was removed with a gentle PBS wash and the media replaced prior to imaging. For assessment of distribution and colocalization of $\mathrm{ABY}_{\mathrm{B} 7-\mathrm{H} 3}-\mathrm{AF} 633$ with Lysosomes-GFP in live cells, dishes were imaged while at $37{ }^{\circ} \mathrm{C}$ and in a $5 \% \mathrm{CO}_{2}$ environment at $20 \times$ objective using a Zeiss LSM 510 Meta NLO imaging system equipped with argon and HeNe lasers and mounted on a vibration-free table for confocal fluorescence microscopy. ImageJ software was used to optimize image brightness and contrast and display colocalized colors.

\section{Murine Model of Breast Cancer Development.}

All experiments involving animals were approved by the Institutional Administrative Panel on Laboratory Animal Care at Stanford University. A transgenic mouse model of breast cancer (FVB/N-Tg(MMTV-PyMT)634Mul/J) was used ${ }^{57}$ in which mice develop tumors in all 10 mammary glands between 6 and 12 weeks of age. Normal mammary gland controls came from littermates negative for the transgene. Tumor imaging was performed in mice with mammary tumors of 3-10 $\mathrm{mm}$ in size. During the imaging studies, mice were anesthetized with $2 \%$ isoflurane in oxygen flowing at $2 \mathrm{~L} / \mathrm{min}$. Abdominal hair was removed using a depilatory cream. Body temperature was maintained at $37^{\circ} \mathrm{C}$ using heated stages and prewarmed ultrasound (US) imaging gel. $100 \mu \mathrm{L}$ contrast agent ( $\mathrm{ABY}_{\mathrm{B} 7-\mathrm{H} 3}-\mathrm{ICG}$ ) and control ( $\left.\mathrm{ABY}_{\mathrm{SCR}}-\mathrm{ICG}\right)$ as described below were administered through tail vein injection.

\section{In Vivo Imaging and Data Analysis.}

All animals were imaged with sPA and fluorescence molecular imaging methods as described previously. ${ }^{9,58}$ The Vevo-LAZR (21 MHz transducer, lateral and axial resolution of 165 and $74 \mu \mathrm{m}$, respectively, $10 \mathrm{~mJ} / \mathrm{cm}^{2}$ average fluence, $10 \mathrm{~ns}$ pulse width, $20 \mathrm{~Hz}$ pulse repetition frequency) was used to capture single-plane, transverse, multiwavelength photoacoustic images (680-900 nm, $10 \mathrm{~nm}$ increments) of each mammary gland. Images were obtained with focal depth at the maximal gland diameter. Co-registered B-mode US images were used for gland localization. A constant distance of $9 \mathrm{~mm}$ was maintained between the transducer and the surface of the skin coupled with a clear, colorless gel to maintain even light distribution throughout the image and provide consistency between time points. Between imaging time points, B-mode US images of each gland were used as references to confirm accurate imaging planes. The Xenogen IVIS Spectrum was used to collect full body fluorescence imaging (excitation 710/30 nm and emission 820/20 nm). Mice were placed in a supine positioned to display all ten mammary glands for imaging.

An in-house MATLAB script was used to measure B7-H3-targeted sPA signal. The B-mode US image corresponding to each sPA image was used to select a region of interest (ROI) over the entire mammary gland. ROIs were hand drawn on the B-mode US images to outline the entire tumor detectable by boundaries of skin and fatty tissue. Wavelength dependent 
changes in signal amplitude were compared to known optical absorption properties of ICG and oxygenated and deoxygenated hemoglobin using linear regression methods. The known spectrum of the probe was used to generate images to determine molecular sPA signal within the ROI. ${ }^{9,59}$ The average sPA signal designated as containing B7-H3 in each ROI was divided by before injection signal to yield the relative fold change in molecular B7-H3 signal within the gland.

For quantitative measurements of fluorescent signal, Living Image Software 4.0 (PerkinsElmer) was used to place ROIs of consistent size over each gland. The average radiant efficiency $\left(\mathrm{p} / \mathrm{s} / \mathrm{cm}^{2} / \mathrm{sr}\right) /\left(\mu \mathrm{W} / \mathrm{cm}^{2}\right)$ of each gland pre- and post-injection was measured. For each animal, background blood pool signal was measured with a ROI placed over the sternum. Fluorescence signal ratios were calculated as the average radiant efficiency in the tumor or normal glands over the background signal for all time points. Initial ratios and post-injection ratios were compared to analyze signal increase. Additionally, abdominal signal was measured by a same size ROI placed over the liver and bowel of each animal.

\section{Biodistribution of $A B Y_{B 7-H 3}-I C G$ and Optimal Imaging Time Point Study.}

To visualize contrast agent distribution to tumors as opposed to nonspecific accumulation in organs, whole body fluorescence imaging of mice with or without tumors was performed

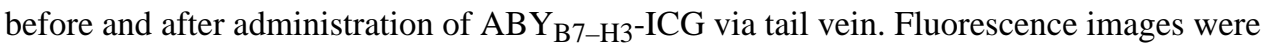
acquired $0,2,4,8,24$, and $48 \mathrm{~h}$ post-intravenous tail vein injection of $33 \mu \mathrm{g}$ of $\mathrm{ABY}_{\mathrm{B} 7-\mathrm{H}^{-}}$ ICG into both transgene negative ( $n=2$ mice, 20 glands) and tumor positive ( $n=2$ mice, 20 glands) groups. Additionally, two tumor-bearing and two transgene negative control mice were euthanized $24 \mathrm{~h}$ post-intravenous tail vein injection and ex vivo fluorescence images were acquired of their mammary glands. A $24 \mathrm{~h}$ time-point, live animal fluorescence imaging of tumor-bearing mice ( $n=2$ mice, 20 glands) was also performed with $33 \mu \mathrm{g}$ of control probe, $\mathrm{ABY}_{\mathrm{SCR}}-\mathrm{ICG}$.

\section{In Vivo Minimum Dosage Study.}

The minimum dose of $\mathrm{ABY}_{\mathrm{B} 7-\mathrm{H} 3}-\mathrm{ICG}$ required for in vivo visualization of molecular sPA and fluorescence signal in tumors was determined by testing several dosages of $\mathrm{ABY}_{\mathrm{B} 7-\mathrm{H} 3^{-}}$ ICG. Based on our previously optimized protocol for anti-B7-H3-antibody-based SPA imaging study, ${ }^{9}$ tumor positive animals received dosages of $20 \mu \mathrm{g}, 33 \mu \mathrm{g}$, and $50 \mu \mathrm{g}(\mathrm{n}=2$

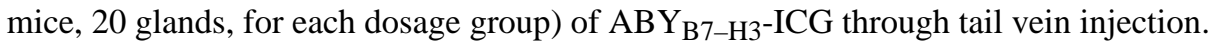
Images were collected with both imaging modalities before and $24 \mathrm{~h}$ after injection for comparison. The smallest dosage of $\mathrm{ABY}_{\mathrm{B} 7-\mathrm{H} 3}-\mathrm{ICG}$ displaying significant increase in signal in vivo was selected for subsequent studies.

\section{In Vivo Imaging Time Point Study.}

Due to the unique pharmacokinetics of $\mathrm{ABY}_{\mathrm{B} 7-\mathrm{H} 3}-\mathrm{ICG}$ contrast agent, the optimal time point for sPA imaging of mammary tumors was determined. Tumor positive mice $(n=2$ mice, 20 glands) and tumor negative mice ( $n=2$ mice, 20 glands) received the established minimum dosage ( $33 \mu \mathrm{g})$ of $\mathrm{ABY}_{\mathrm{B} 7-\mathrm{H} 3}-\mathrm{ICG}$ via tail vein injection. The mice were imaged with sPA and fluorescence imaging before injection and 2, 4, 8, 24, and $48 \mathrm{~h}$ post-injection. 
The optimal imaging time point was set at that which showed the highest B7-H3 sPA signal increase from the pre-injection levels in tumor but not the normal mammary glands.

\section{In Vivo sPA Molecular Imaging of Mammary Tumors.}

To assess the ability of the $\mathrm{ABY}_{\mathrm{B} 7-\mathrm{H} 3}-\mathrm{ICG}$ to indicate molecular $\mathrm{B} 7-\mathrm{H} 3$ signal in vivo, we performed sPA imaging of mammary tumors of transgenic mice $24 \mathrm{~h}$ after injection of $33 \mu \mathrm{g}$

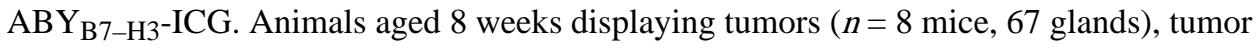
positive animals blocked with $100 \mu \mathrm{g}$ of unconjugated $\mathrm{ABY}_{\mathrm{B} 7-\mathrm{H} 3} 24 \mathrm{~h}$ prior $(n=4$ mice, 40 glands) to the administration of contrast agent, and tumor negative littermates ( $n=3$ mice, 30 glands) underwent sPA imaging. In addition, $33 \mu \mathrm{g}$ of $\mathrm{ABY}_{\mathrm{SCR}}-\mathrm{ICG}$ contrast agent was also tested in tumor-bearing mice ( $n=2$ mice, 20 glands) for sPA imaging. The blocked, control agent, and tumor negative groups served as controls to confirm binding specificity of $\mathrm{ABY}_{\mathrm{B} 7-\mathrm{H} 3}-\mathrm{ICG}$.

\section{Statistical Analysis.}

Data graphs were generated using GraphPad Prism software. Student's $t$ test was used to compare statistical significance between the experimental groups and standard deviation of mean is shown to represent variation in experimental observations. Boxplots are plotted based on Tukey rules.

\section{Supplementary Material}

Refer to Web version on PubMed Central for supplementary material.

\section{ACKNOWLEDGMENTS}

The authors would like to acknowledge Dr. Juergen K. Willmann for his mentorship. We acknowledge Kenneth Lau from the Proteomics Resource Facility in the Canary Center for Cancer Early Detection at Stanford for performing the mass spectrometry analysis. This study was supported by American Cancer Society 130418-RSG-17-110-01TBG (BJH), NIH R21EB022214 (KEW), and NIH K99EB023279 (KEW). The Stanford Neuroscience Microscopy Service was supported by NIH NS069375. The Vevo LAZR was upgraded under grant NIH 1-S10-OD01034401.

\section{ABBREVIATIONS}

$\begin{array}{ll}\text { PA } & \text { photoacoustic } \\ \text { SPA } & \text { spectroscopic photoacoustic } \\ \text { US } & \text { ultrasound } \\ \text { ICG } & \text { indocyanine green } \\ \text { ScFv } & \text { single-chain variable fragment } \\ \text { ABY } & \text { affibody } \\ \text { MMTV } & \text { mouse mammary tumor virus } \\ \text { EGFR } & \text { epidermal growth factor receptor } \\ \text { MALDI-TOF } & \text { matrix-assisted laser desorption ionization time-of-flight }\end{array}$




\section{REFERENCES}

(1). Siegel RL, Miller KD, and Jemal A (2019) Cancer Statistics, 2019. Ca-Cancer J. Clin 69, 7-34. [PubMed: 30620402]

(2). Boyd NF, Guo H, Martin LJ, Sun L, Stone J, Fishell E, Jong RA, Hislop G, Chiarelli A, Minkin S, et al. (2007) Mammographic Breast Density and the Risk and Detection of Breast Cancer. N. Engl. J. Med 356, 227-236. [PubMed: 17229950]

(3). Engmann NJ, Golmakani MK, Miglioretti DL, Sprague BL, and Kerlikowske K (2017) Population-attributable risk proportion of clinical risk factors for breast cancer. JAMA Oncol. 3 (9), 1228-1236. [PubMed: 28152151]

(4). Scheel JR, Lee JM, Sprague BL, Lee CI, and Lehman CD (2015) Screening ultrasound as an adjunct to mammography in women with mammographically dense breasts. Am. J. Obstet. Gynecol 212 (1), 9-17. [PubMed: 24959654]

(5). Sprague BL, Stout NK, Schechter C, van Ravesteyn NT, Cevik M, Alagoz O, Lee CI, van den Broek JJ, Miglioretti DL, Mandelblatt JS, et al. (2015) Benefits, harms, and cost-effectiveness of supplemental ultrasonography screening for women with dense breasts. Ann. Intern. Med 162 (3), 157-166. [PubMed: 25486550]

(6). Hooley RJ, Greenberg KL, Stackhouse RM, Geisel JL, Butler RS, and Philpotts LE (2012) Screening US in Patients with Mammographically Dense Breasts: Initial Experience with Connecticut Public Act 09-41. Radiology 265 (1), 59-69. [PubMed: 22723501]

(7). Menke J (2015) Photoacoustic breast tomography prototypes with reported human applications. Eur. Radiol 25 (8), 2205-2213. [PubMed: 25721319]

(8). Wilson KE, Wang TY, and Willmann JK (2013) Acoustic and Photoacoustic Molecular Imaging of Cancer. J. Nucl. Med 54 (11), 1851-1854. [PubMed: 24187042]

(9). Wilson KE, Bachawal SV, Abou-Elkacem L, Jensen K, Machtaler S, Tian L, and Willmann JK (2017) Spectroscopic photoacoustic molecular imaging of breast cancer using a B7-H3-targeted ICG contrast agent. Theranostics 7 (6), 1463-1476. [PubMed: 28529630]

(10). Heijblom M, Piras D, Xia W, van Hespen JCG, Klaase JM, van den Engh FM, van Leeuwen TG, Steenbergen W, and Manohar S (2012) Visualizing breast cancer using the Twente photoacoustic mammoscope: What do we learn from twelve new patient measurements? Opt. Express 20 (11), 11582. [PubMed: 22714144]

(11). Reinhardt CJ, and Chan J (2018) Development of Photoacoustic Probes for in Vivo Molecular Imaging. Biochemistry 57 (2), 194-199. [PubMed: 29022344]

(12). Luke GP, Yeager D, and Emelianov SY (2012) Biomedical applications of photoacoustic imaging with exogenous contrast agents. Ann. Biomed. Eng 40 (2), 422-437. [PubMed: 22048668]

(13). Ogawa M, Kosaka N, Choyke PL, and Kobayashi H (2009) In vivo molecular imaging of cancer with a quenching near-infrared fluorescent probe using conjugates of monoclonal antibodies and indocyanine green. Cancer Res. 69 (4), 1268-1272. [PubMed: 19176373]

(14). Hellebust R, and Richards-Kortum A (2012) Advances in molecular imaging: targeted optical contrast agents for cancer diagnostics. Nanomedicine 7 (3), 429-445. [PubMed: 22385200]

(15). Teraphongphom N, Kong CS, Warram JM, and Rosenthal EL (2017) Specimen mapping in head and neck cancer using fluorescence imaging. Laryngoscope Investig. Otolaryngol 2 (6), 447-452.

(16). Sockolosky JT, and Szoka FC (2015) The neonatal Fc receptor, FcRn, as a target for drug delivery and therapy. Adv. Drug Delivery Rev. 91, 109.

(17). Sun X, Li Y, Liu T, and Li Z (2017) Peptide-based imaging agents for cancer detection. Adv. Drug Delivery Rev 110-111, 38-51.

(18). Weissleder R (2001) A clearer vision for in vivo imaging. Nat. Biotechnol 19 (4), 316-317. [PubMed: 11283581]

(19). Massoud TF, and Gambhir S (2003) Molecular imaging in living subjects: seeing fundamental biological processes in a new light. Genes Dev. 17 (5), 545-580. [PubMed: 12629038] 
(20). Gray BP, and Brown KC (2014) Combinatorial peptide libraries: Mining for cell-binding peptides. Chem. Rev 114 (2), 1020-1081. [PubMed: 24299061]

(21). Kim HY, Wang X, Wahlberg B, and Edwards WB (2014) Discovery of hapten-specific scFv from a phage display library and applications for HER2-positive tumor imaging. Bioconjugate Chem. 25 (7), 1311-1322.

(22). Löfblom J, Feldwisch J, Tolmachev V, Carlsson J, Ståhl S, and Frejd FY (2010) Affibody molecules: Engineered proteins for therapeutic, diagnostic and biotechnological applications. FEBS Lett. 584 (12), 2670-2680. [PubMed: 20388508]

(23). Woldring DR, Holec PV, Stern LA, Du Y, and Hackel BJ (2017) A gradient of sitewise diversity promotes evolutionary fitness for binder discovery in a three-helix bundle protein scaffold. Biochemistry 56 (11), 1656-1671. [PubMed: 28248518]

(24). Nord K, Gunneriusson E, Ringdahl J, Stahl S, Uhlen M, and Nygren P (1997) Combinatorial libraries of an a-helical bacterial receptor domain. Nat. Biotechnol 15, 772-777. [PubMed: 9255793]

(25). Wahlberg E, Lendel C, Helgsttrand M, Allard P, Dincbas-Renqvist V, Hedqvist A, Berglund H, Nygren P, and Hard T (2003) An affibody in complex with a target protein: Structure and coupled folding. Proc. Natl. Acad. Sci. U. S. A 100 (6), 3185-3190. [PubMed: 12594333]

(26). Ståhl S, Gräslund T, Eriksson Karlström A, Frejd FY, and Nygren PA (2017) Affibody Molecules in Biotechnological and Medical Applications. Trends Biotechnol. 35 (8), 691-712. [PubMed: 28514998]

(27). Friedman M, and Ståhl S (2009) Engineered affinity proteins for tumour-targeting applications. Biotechnol. Appl. Biochem 53 (1), 1-29. [PubMed: 19341363]

(28). Tolmachev V, Grönroos TJ, Yim CB, Garousi J, Yue Y, Grimm S, Rajander J, Perols A, ta-Solin MH, Solin O, et al. (2018) Molecular design of radiocopper-labelled Affibody molecules. Sci. Rep 8 (1), 2-11. [PubMed: 29311662]

(29). Baum RP, Prasad V, Muller D, Schuchardt C, Orlova A, Wennborg A, Tolmachev V, and Feldwisch J (2010) Molecular Imaging of HER2-Expressing Malignant Tumors in Breast Cancer Patients Using Synthetic ${ }^{111}$ In- or ${ }^{68}$ Ga-Labeled Affibody Molecules. J. Nucl. Med 51 (6), 892897. [PubMed: 20484419]

(30). Bachawal SV, Jensen KC, Wilson KE, Tian L, Lutz AM, and Willmann JK (2015) Breast cancer detection by B7-H3-targeted ultrasound molecular imaging. Cancer Res. 75 (12), 2501-2509. [PubMed: 25899053]

(31). Wilson KE, Bachawal SV, and Willmann JK (2018) Intraoperative resection guidance with photoacoustic and fluores-cence molecular imaging using an anti-B7-H3 antibody- indocyanine green dual contrast agent. Clin. Cancer Res. 24 (15), 3572-3582. [PubMed: 29712688]

(32). Seaman S, Zhu Z, Saha S, Zhang XM, Yang MY, Hilton MB, Morris K, Szot C, Morris H, Swing DA, et al. (2017) Eradication of Tumors through Simultaneous Ablation of CD276/B7-H3Positive Tumor Cells and Tumor Vasculature. Cancer Cell 31 (4), 501-515. [PubMed: 28399408]

(33). Stern LA, Lown P, Kobe AC, Abou-Elkacem L, Willmann JK, and Hackel BJ (2019) CellularBased Selections Aid Yeast-Display Discovery of Genuine Cell-Binding Ligands: Targeting Oncology Vascular Biomarker CD276. ACS Comb. Sci 21 (3), 207-222. [PubMed: 30620189]

(34). Oraevsky AA, Clingman B, Zalev J, Stavros AT, Yang WT, and Parikh JR (2018) Clinical optoacoustic imaging combined with ultrasound for coregistered functional and anatomical mapping of breast tumors. Photoacoustics. 12, 30-45. [PubMed: 30306043]

(35). Mostafa A, Nandy S, Amidi E, and Zhu Q (2018) Dual-mode photoacoustic and ultrasound system for real-time in-vivo ovarian cancer imaging. Photons Plus Ultrasound Imaging Sens, 158.

(36). James J, Murukeshan VM, and Woh LS (2014) Integrated photoacoustic, ultrasound and fluorescence platform for diagnostic medical imaging-proof of concept study with a tissue mimicking phantom. Biomed. Opt. Express 5 (7), 2135. [PubMed: 25071954]

(37). Liu H, Tekle C, Chen YW, Kristian A, Zhao Y, Zhou M, Liu Z, Ding Y, Wang B, and Maelandsmo GM (2011) B7-H3 silencing increases paclitaxel sensitivity by abrogating Jak2/ Stat3 phosphorylation. Mol. Cancer Ther 10, 960. [PubMed: 21518725] 
(38). Kobayashi H, Ogawa M, Alford R, Choyke PL, and Urano Y (2010) New Strategies for Fluorescent Probe Design in Medical Diagnostic Imaging. Chem. Rev 110 (5), 2620-2640. [PubMed: 20000749]

(39). Sun M, Richards S, Prasad DVR, Mai M, Rudensky A, and Dong C (2002) Characterization of Mouse and Human B7-H3 Genes. J. Immunol 168, 6294-6297. [PubMed: 12055244]

(40). Faybik P, and Hetz H (2006) Plasma Disappearance Rate of Indocyanine Green in Liver Dysfunction. Transplant. Proc 38 (3), 801-802. [PubMed: 16647475]

(41). Reagan-Shaw S, Nihal M, and Ahmad N (2008) Dose translation from animal to human studies revisited. FASEB J. 22 (3), 659-61. [PubMed: 17942826]

(42). Lobo ED, Hansen RJ, and Balthasar JP (2004) Antibody pharmacokinetics and pharmacodynamics. J. Pharm. Sci 93 (11), 2645-2668. [PubMed: 15389672]

(43). Altai M, Liu H, Ding H, Mitran B, Edqvist PH, Tolmachev V, Orlova A, and Graslund T (2018) Affibody-derived drug conjugates: Potent cytotoxic molecules for treatment of HER2 overexpressing tumors. J. Controlled Release 288, 84-95.

(44). Samkoe KS, Gunn JR, Marra K, Hull SM, Moodie KL, Feldwisch J, Strong TV, Draney DR, Hoopes PJ, Roberts DW, et al. (2017) Toxicity and Pharmacokinetic Profile for Single-Dose Injection of ABY-029: a Fluorescent Anti-EGFR Synthetic Affibody Molecule for Human Use. Mol. Imaging Biol. 19 (4), 512-521. [PubMed: 27909986]

(45). Frejd FY, and Kim KT (2017) Affibody molecules as engineered protein drugs. Exp. Mol. Med 49 (3), No. e306. [PubMed: 28336959]

(46). Miller-Kleinhenz JM, Bozeman EN, and Yang L (2015) Targeted nanoparticles for image-guided treatment of triple-negative breast cancer: Clinical significance and technological advances. Wiley Interdiscip. Rev. Nanomedicine Nanobiotechnology. 7 (6), 797-816. [PubMed: 25966677]

(47). Freise AC, and Wu AM (2015) In vivo Imaging with Antibodies and Engineered Fragments. Mol. Immunol 67 (200), 142-152. [PubMed: 25934435]

(48). Harding FA, Stickler MM, Razo J, and DuBridge RB (2010) The immunogenicity of humanized and fully human antibodies: Residual immunogenicity resides in the CDR regions. MAbs. 2 (3), 256-265. [PubMed: 20400861]

(49). Roubidoux MA, Bailey JE, Wray L, and Helvie MA (2004) Invasive Cancers Detected after Breast Cancer Screening Yielded a Negative Result: Relationship of Mammographic Density to Tumor Prognostic Factors. Radiology 230 (1), 42-48. [PubMed: 14695385]

(50). Fakhrejahani E, Torii M, Kitai T, Kanao S, Asao Y, Hashizume Y, Mikami Y, Yamaga I, Kataoka M, Sugie T, et al. (2015) Clinical report on the first prototype of a photoacoustic tomography system with dual illumination for breast cancer imaging. PLoS One 10 (10), 1-13.

(51). Wang S, Lin J, Wang T, Chen X, and Huang P (2016) Recent advances in photoacoustic imaging for deep-tissue biomedical applications. Theranostics 6 (13), 2394-2413. [PubMed: 27877243]

(52). Wang J, Jeevarathinam AS, Humphries K, Jhunjhunwala A, Chen F, Hariri A, Miller BR III, and Jokerst JV (2018) A Mechanistic Investigation of Methylene Blue and Heparin Inter-actions and Their Photoacoustic Enhancement. Bioconjugate Chem. 29 (11), 3768-3775.

(53). Wang J, Lin CY, Moore C, Jhunjhunwala A, and Jokerst JV (2018) Switchable Photoacoustic Intensity of Methylene Blue via Sodium Dodecyl Sulfate Micellization. Langmuir 34 (1), 359365. [PubMed: 29232146]

(54). Yaghjyan L, Pettersson A, Colditz GA, Collins LC, Schnitt SJ, Beck AH, Rosner B, Vachon C, and Tamimi RM (2015) Postmenopausal mammographic breast density and sub-sequent breast cancer risk according to selected tissue markers. Br. J. Cancer 113 (7), 1104-1113. [PubMed: 26335607]

(55). Valluru KS, Wilson KE, and Willmann JK (2016) Photoacoustic imaging in oncology: Translational Preclinical and Early Clinical Experience. Radiology 280, 332. [PubMed: 27429141]

(56). Zhao Y, Kim YS, Milenic DE, Baidoo KE, and Brechbiel MW (2014) In vitro \& in vivo analysis of indocyanine green-labeled panitumumab for optical imaging: a cautionary tale. Bioconjugate Chem. 25, 1801-1810.

(57). Cardiff RD (2001) Validity of mouse mammary tumour models for human breast cancer: Comparative pathology. Microsc. Res. Tech 52 (2), 224-30. [PubMed: 11169869] 
(58). Wilson KE, Bachawal SV, Tian L, and Willmann JK (2014) Multiparametric spectroscopic photoacoustic imaging of breast cancer development in a transgenic mouse model. Theranostics 4 (11), 1062-1071. [PubMed: 25285161]

(59). Danielli A, Maslov K, Favazza CP, Xia J, and Wang LV (2015) Nonlinear photoacoustic spectroscopy of hemoglobin. Appl. Phys. Lett 106, 203701. [PubMed: 26045627] 
(I) Characterization of $A B Y_{B 7-H 3}-I C G$ contrast agent by UV spectrophotometry

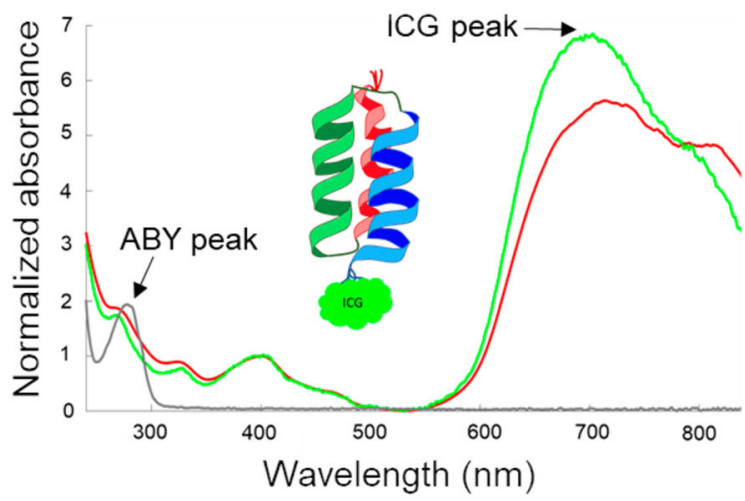

(II) In-vivo contrast agent optimization: minimum dose \& time-point for fluorescence and SPA imaging

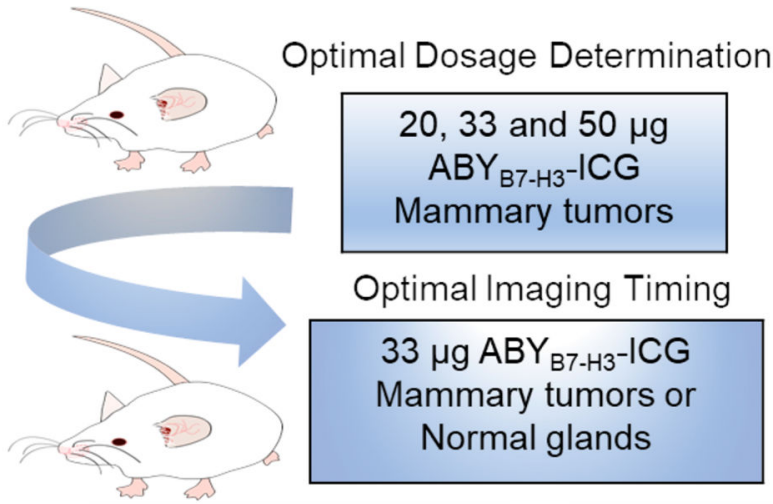

(III) Molecular imaging of mammary tumors with $A B Y_{B 7-H 3}-I C G$

Fluorescence

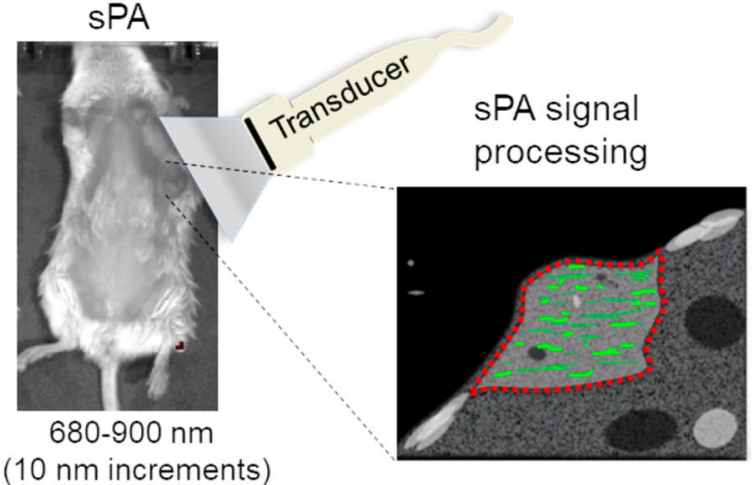

Figure 1.

Study overview of $\mathrm{ABY}_{\mathrm{B} 7-\mathrm{H} 3}-\mathrm{ICG}$ contrast agent development for spectroscopic photoacoustic (sPA) imaging of mammary tumors. (I) B7-H3 targeting ABY protein $\left(\mathrm{ABY}_{\mathrm{B} 7-\mathrm{H} 3}\right)$ was recombinantly produced and conjugated to a fluorescence ICG dye for characterization. UV-visible spectroscopy-based normalized curves of ICG-conjugated protein (red), ICG (green), and unconjugated protein (gray). (II) Conjugated optical probe,

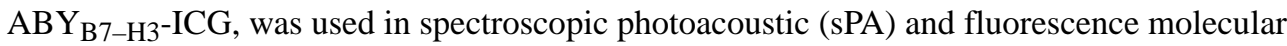
imaging of breast cancer to determine in vivo minimum dosage in MMTV-PyMT transgenic mouse model. Photoacoustic and fluorescence molecular images were acquired at 0, 2, 4, 8, 24, $48 \mathrm{~h}$ post-injection to determine optimal imaging time point. (III) Finally, fluorescence signal and B-mode ultrasound-guided SPA molecular signal was processed and quantified in breast tumors and normal mammary glands at $24 \mathrm{~h}$ post injection of $33 \mu \mathrm{g}$ of contrast agent. Excitation (Ex) and Emission (Em) wavelengths for fluorescence imaging and image acquisition wavelengths for sPA imaging are provided. 

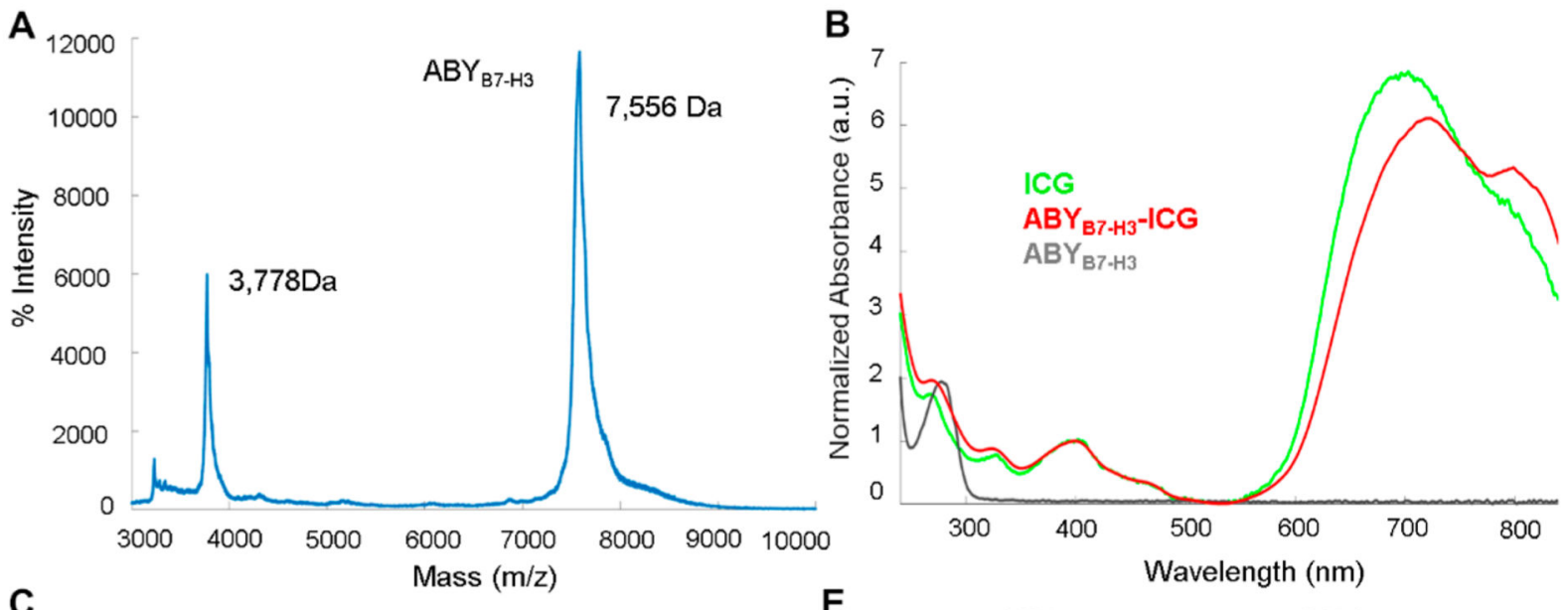

C

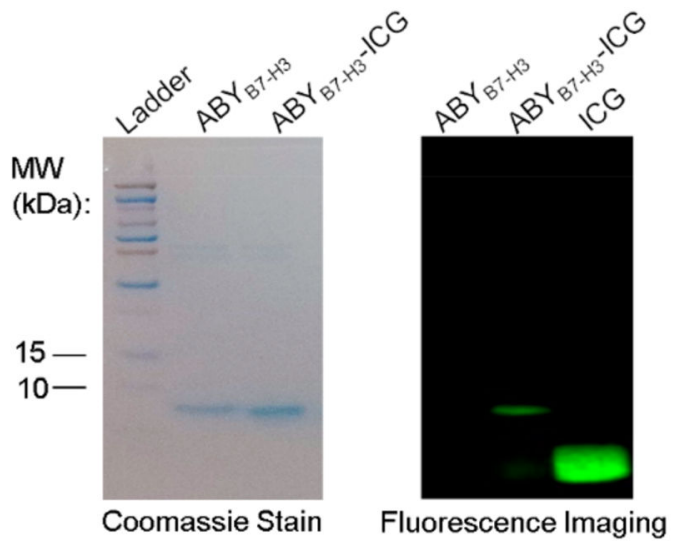

D

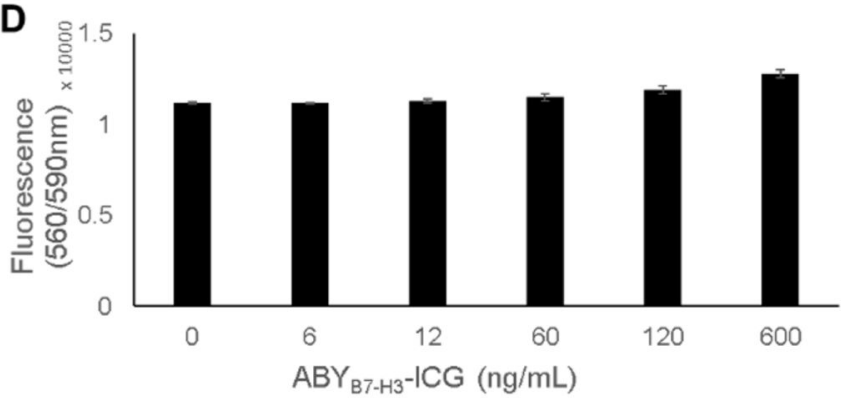

E
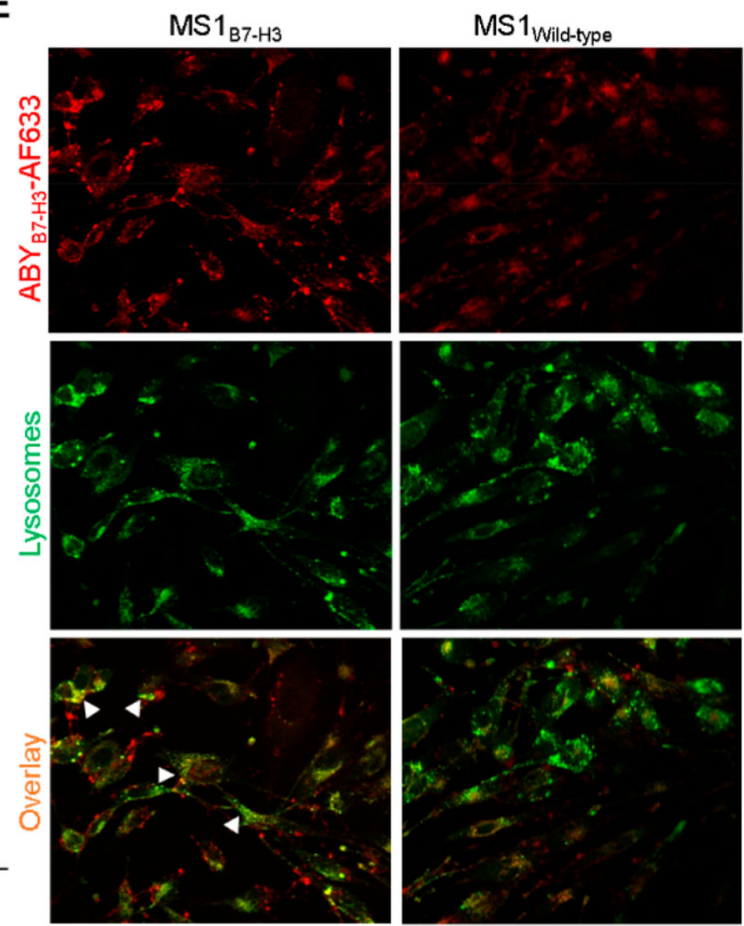

Figure 2.

Characterization of ABYB7-H3-ICG contrast agent. (A) Mass spectra showing approximate molecular weight of $\mathrm{ABY}_{\mathrm{B} 7-\mathrm{H} 3}$ (Expected mass: $7517 \mathrm{Da}$; Observed mass: $7556 \mathrm{Da}$ ) associated with the mass-to-charge ratio $(\mathrm{m} / \mathrm{z})$ of the dominant peak. The second major peak is a doubly charged species of $\mathrm{ABY}$. (B) UV-visible spectroscopy of the $\mathrm{ABY}_{\mathrm{B} 7-\mathrm{H} 3}$, unconjugated ICG-NHS, and $\mathrm{ABY}_{\mathrm{B} 7-\mathrm{H} 3}-\mathrm{ICG}$. $\mathrm{ABY}_{\mathrm{B} 7-\mathrm{H} 3}$ peaks at $280 \mathrm{~nm}$, while the

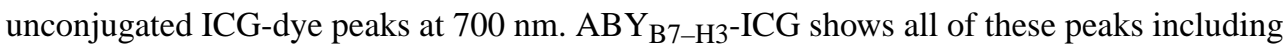
ICG spectral shift at $800 \mathrm{~nm}$, confirming conjugation and allowing for a dye/ABY $\mathrm{B} 7-\mathrm{H} 3$ ratio calculation of 1.0. (C) SDS-PAGE showing ABY peptide bands around 7.5 kDa in size. Note the high purity of recombinantly produced and chromatographically separated ABY. The near-infrared fluorescence image shows ICG dye signal present in the conjugated ABY $\left(\mathrm{ABY}_{\mathrm{B} 7-\mathrm{H} 3}-\mathrm{ICG}\right)$ compared to nonconjugated $\mathrm{ABY}_{\mathrm{B} 7-\mathrm{H} 3}$. Note the absence of free ICG dye 
in the contrast agent after purification. (D) B7-H3-expressing human MDA-MB-231 cells were incubated with 0-600 ng/mL ABY $\mathrm{B}_{-\mathrm{H} 3}$ and assayed for viability (fluorescent signal corresponds to viability). The lack of decreased signal is consistent with a lack of toxicity. (E) Immunofluorescent images showing lysosomal (green) uptake of agent (red; $\mathrm{ABY}_{\mathrm{B} 7-\mathrm{H}^{-}}$ AF633) in $1 \mathrm{~h}$ by $\mathrm{MS} 1_{\text {wild-type }}$ and $\mathrm{MS} 1_{\mathrm{B} 7-\mathrm{H} 3}$ cells. Compared to the MS1 $1_{\text {wild-type }}$ cells, $\mathrm{MS1}_{\mathrm{B} 7-\mathrm{H} 3}$ cells had increased lysosomal colocalization of $\mathrm{ABY}$ (white arrowheads pointing to yellow signal in the overlay image). 

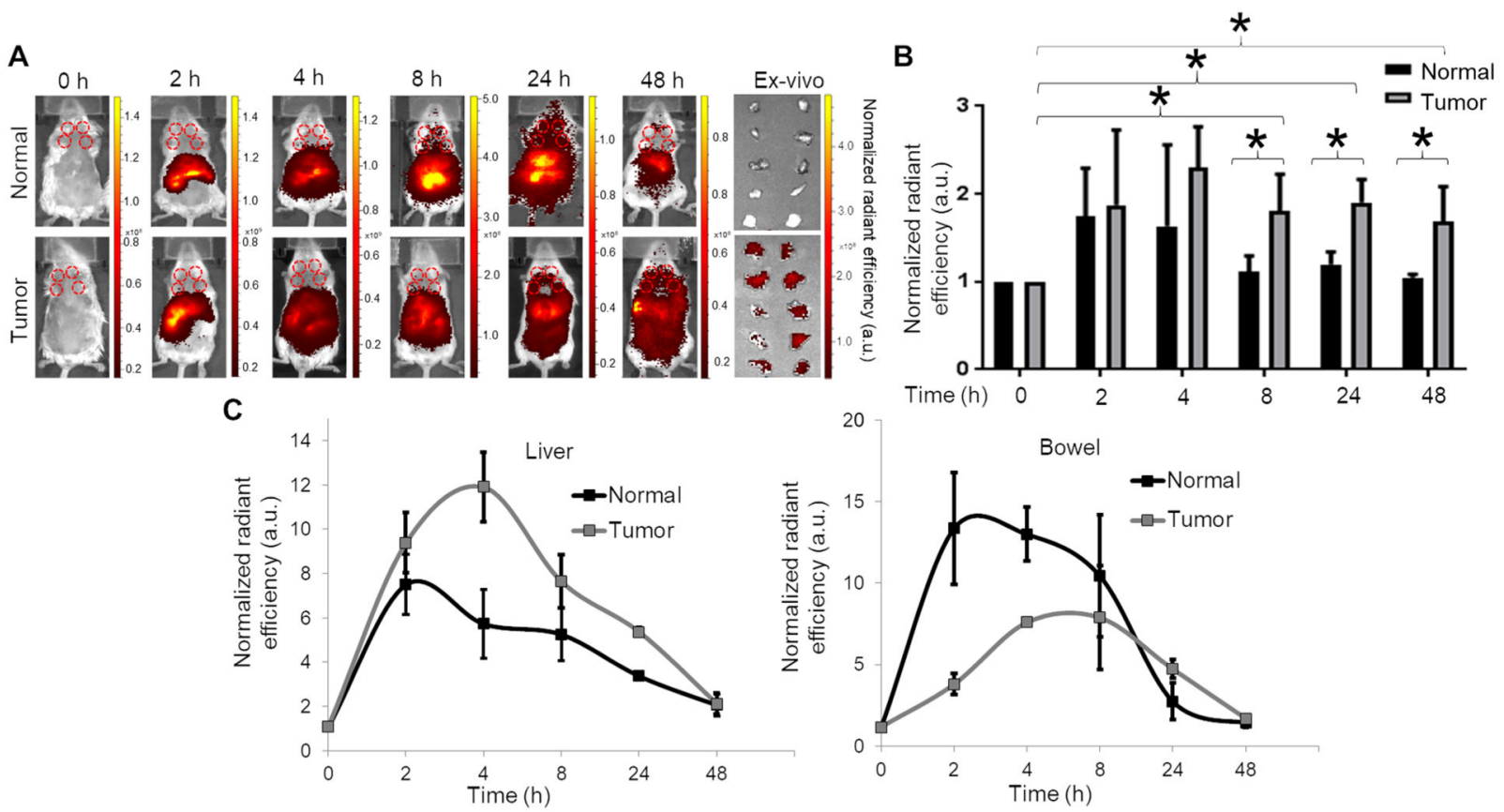

Figure 3.

Biodistribution of ABYB7-H3-ICG in transgenic breast cancer mouse model. (A) In vivo

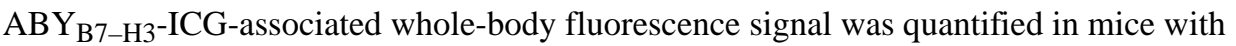
normal glands $(n=20)$ and mammary tumors $(n=20)$ at various time-points in hours $(\mathrm{h})$ post contrast agent administration. ROIs (dotted red lines) were drawn around the tumors or normal glands as shown. Fluorescence signal from glands as well as abdominal area including liver and bowel indicated contrast agent distribution. Note: Dynamic range scales are variable between time points, though not between normal and tumor animals at a given time point, and noted next to the image sets. Right panel: Example of ex vivo fluorescence imaging of all ten normal or tumor-bearing glands from mice at $24 \mathrm{~h}$ after $\mathrm{ABY}_{\mathrm{B} 7-\mathrm{H} 3-\mathrm{ICG}}$ injection. Average tumor fluorescence is 2.2-fold higher and normal gland fluorescence is 0.9 -fold of the background signal. (B) The fluorescence signal, normalized to the initial condition, exhibits significantly $(* p<0.05)$ increased fluorescence signal from breast tumors compared to normal mammary glands at 8, 24, and $48 \mathrm{~h}$. Compared to the background signal at $0 \mathrm{~h}$ time-point, tumor signal but not the normal gland signal was significantly increased $(* p<0.05)$ at 8,24 , and $48 \mathrm{~h}$. (C) The fluorescence signal, normalized to the initial condition, from liver and bowel of normal and tumor mouse groups is plotted for 0 to $48 \mathrm{~h}$ after administration of contrast agent. 

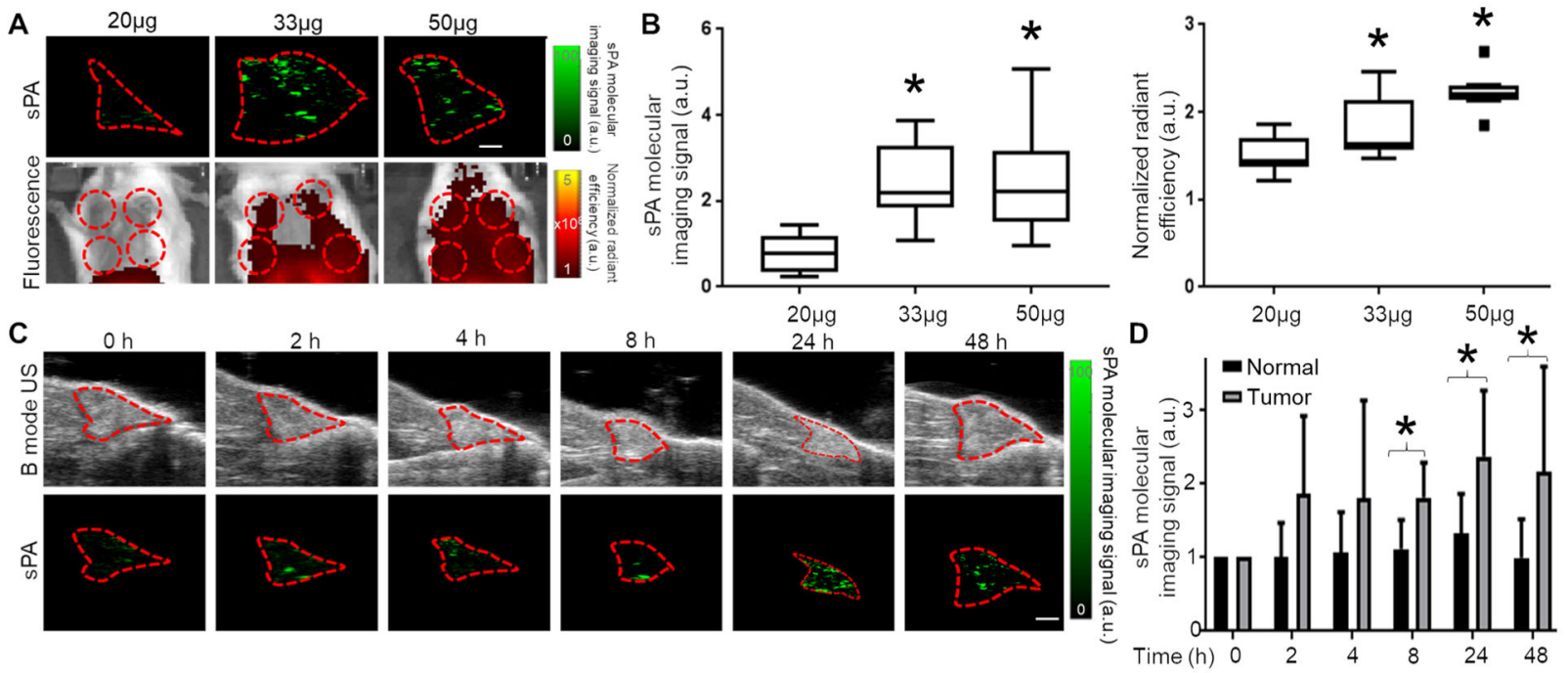

Figure 4.

In vivo minimum dosage and time point analysis of ABYB7-H3-ICG. (A) Representative sPA (top) and fluorescence (bottom) images of tumor positive mice ( $n=20 /$ group) $24 \mathrm{~h}$ post-injection of 20,33 , or $50 \mu \mathrm{g}$ of $\mathrm{ABY}_{\mathrm{B} 7-\mathrm{H} 3}-\mathrm{ICG}$. Single-plane, transverse, multiwavelength PA images (680-900 nm, $10 \mathrm{~nm}$ increments) were acquired. ROIs (dotted red lines) were drawn around the tumors (sPA image scale bar $=1 \mathrm{~mm}$ ). (B) Boxplots of sPA (left panel) and fluorescent signal (right panel) normalized to signal before contrast agent administration within tumors from each dosage. The smallest dosage that shows a significant $(* p<0.05)$ fold change increase in sPA signal was $33 \mu \mathrm{g}(2.4 \pm 0.9 \mathrm{au})$ followed by the 50 $\mu \mathrm{g}$ dose $(2.5 \pm 1.3 \mathrm{au})$. Fluorescence signal was also significantly increased with $33 \mu \mathrm{g}$ (1.8 $\pm 0.4 \mathrm{au})$ and $50 \mu \mathrm{g}(2.2 \pm 0.2 \mathrm{au})$ doses. Box-plots follow Tukey rules. (C) Representative images (B-mode ultrasound (US), top; sPA, bottom) of tumor positive mice taken at various

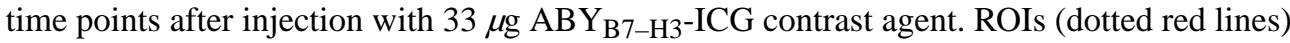
indicate tumor area. An increase in SPA signal is obtained at 8, 24, and $48 \mathrm{~h}$ time-points (Scale bar $=1 \mathrm{~mm})$. (D) Bar graphs of normalized sPA signal ratios in both tumors and normal glands after injection with $33 \mu \mathrm{g}$ of $\mathrm{ABY}$ B7-H3-ICG. sPA imaging shows a statistically significant $(* p<0.05)$ increase in B7-H3 molecular imaging signal in tumors versus normal glands at 8,24 , and $48 \mathrm{~h}$. 

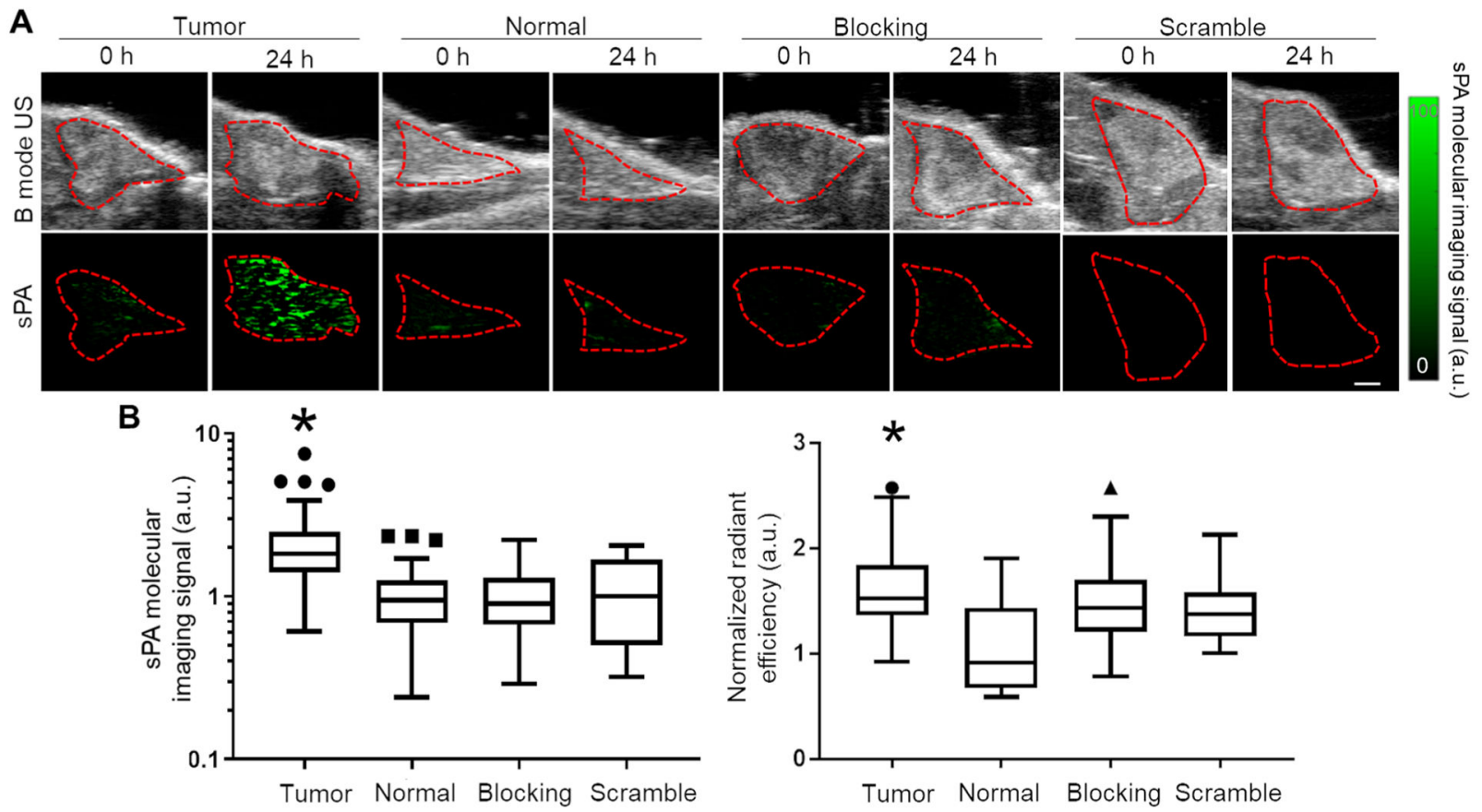

Figure 5.

In vivo sPA imaging of breast tumor and normal mammary glands. (A) Paired B-mode ultrasound (US) and sPA images of mammary tumors $(n=67)$ and normal glands before and $24 \mathrm{~h}$ after injection with $33 \mu \mathrm{g}$ of $\mathrm{ABY}_{\mathrm{B} 7-\mathrm{H} 3}-\mathrm{ICG}$ or $\mathrm{ABY}_{\mathrm{SCR}}-\mathrm{ICG}$ (Scale bar $=1 \mathrm{~mm}$ ). ROIs (dotted red lines) indicate tumor area. Each set of four images represents a single tumor or normal gland at 0 and $24 \mathrm{~h}$. Single-plane, transverse, multiwavelength PA images (680-900 nm, $10 \mathrm{~nm}$ increments) were acquired. Tumor bearing mice injected with $\mathrm{ABY}_{\mathrm{B} 7-\mathrm{H} 3}-\mathrm{ICG}$ showed increased B7-H3 molecular signal. Normal mammary glands $(n=$ $30)$ injected with $\mathrm{ABY} \mathrm{B}_{\mathrm{B}-\mathrm{H} 3}-\mathrm{ICG}$, in vivo blocking of $\mathrm{B} 7-\mathrm{H} 3(n=40)$ with unconjugated $\mathrm{ABY}_{\mathrm{B} 7-\mathrm{H} 3} 24 \mathrm{~h}$ prior to $\mathrm{ABY}_{\mathrm{B} 7-\mathrm{H} 3}-\mathrm{ICG}$ administration, and $\mathrm{ABY}_{\mathrm{SCR}}-\mathrm{ICG}(n=20)$ in the scramble group showed no significant increase in SPA imaging signal. (B) Boxplot of normalized sPA signal (left panel) and fluorescence signal (right panel) of breast tumors, normal mammary glands, tumor blocking, and scramble groups. Tumor group showed a significantly $(* p<0.05)$ higher sPA signal $(2.1 \pm 1.2 \mathrm{au})$ compared to each of the controls: normal glands $(1.1 \pm 0.5 \mathrm{au})$, blocking $(1.0 \pm 0.4 \mathrm{au})$, and $\mathrm{ABY}_{\mathrm{SCR}}-\mathrm{ICG}$ group $(1.1 \pm 0.6$ $\mathrm{au})$. In comparison, tumor group showed a significantly $(* p<0.05)$ higher fluorescence signal $(1.6 \pm 0.4 \mathrm{au})$ compared to only the normal glands $(1.0 \pm 0.4 \mathrm{au})$ and $\mathrm{ABY}_{\mathrm{SCR}}-\mathrm{ICG}$ group (1.4 $\pm 0.3 \mathrm{au})$ but not the blocking group $(1.5 \pm 0.4 \mathrm{au})$. 